University of South Florida

DIGITAL COMMONS Digital Commons @ University of @ UNIVERSITY OF SOUTH FLORIDA South Florida

7-1-2016

\title{
Workforce Development and Succession Planning to Prepare the Rural Transit Industry for the Future
}

CUTR

Follow this and additional works at: https://digitalcommons.usf.edu/cutr_nctr

\section{Recommended Citation}

"Workforce Development and Succession Planning to Prepare the Rural Transit Industry for the Future," National Center for Transit Research (NCTR) Report No. CUTR-NCTR-RR-2016-12, Center for Urban Transportation Research, University of South Florida, 2015.

DOI: https://doi.org/10.5038/CUTR-NCTR-RR-2016-12

Available at: https://scholarcommons.usf.edu/cutr_nctr/56

This Technical Report is brought to you for free and open access by the National Center for Transit Research (NCTR) Archive (2000-2020) at Digital Commons @ University of South Florida. It has been accepted for inclusion in Research Reports by an authorized administrator of Digital Commons @ University of South Florida. For more information, please contact digitalcommons@usf.edu. 


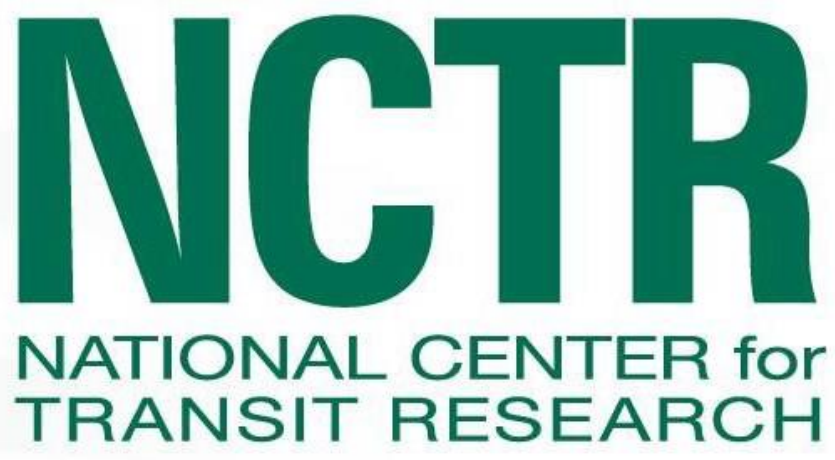

\section{Workforce Development and Succession Planning to Prepare the Rural Transit Industry for the Future}

July 2016

Prepared by

Del Peterson

Ted Rieck

North Dakota State University

Upper Great Plains Transportation Institute Small Urban and Rural Transit Center Fargo, ND 


\section{Disclaimer}

The contents of this report reflect the views of the authors, who are responsible for the facts and the accuracy of the information presented herein. This document is disseminated under the sponsorship of the Department of Transportation University Transportation Centers Program and the Florida Department of Transportation, in the interest of information exchange. The U.S. Government and the Florida Department of Transportation assume no liability for the contents or use thereof.

The opinions, findings, and conclusions expressed in this publication are those of the authors and not necessarily those of the State of Florida Department of Transportation. 


\section{Workforce Development and Succession Planning to Prepare the Rural Transit Industry for the Future}

Prepared for:

U.S. Department of Transportation

Prepared by:

Del Peterson

Ted Rieck

Small Urban and Rural Transit Center

Upper Great Plains Transportation Institute

North Dakota State University

Fargo, ND

Final Report

21177060-NCTR-NDSU07

July 2016

National Center for Transit Research

A USDOT Transit-focused University Transportation Center consortium led by University of South Florida

4202 E. Fowler Avenue, CUT100, Tampa FL 33620-5375 www.nctr.usf.edu

Member universities: University of South Florida, North Dakota State University, University of Illinois at Chicago, Florida International University 


\section{Metric Conversion}

\begin{tabular}{|c|c|c|c|c|}
\hline SYMBOL & WHEN YOU KNOW & MULTIPLY BY & TO FIND & SYMBOL \\
\hline \multicolumn{5}{|c|}{ LENGTH } \\
\hline in & inches & 25.4 & millimeters & $\mathrm{mm}$ \\
\hline ft. & feet & 0.305 & meters & $\mathrm{m}$ \\
\hline yd. & yards & 0.914 & meters & $\mathrm{m}$ \\
\hline mi & miles & 1.61 & kilometers & $\mathrm{km}$ \\
\hline \multicolumn{5}{|c|}{ VOLUME } \\
\hline fl. oz. & fluid ounces & 29.57 & milliliters & $\mathrm{mL}$ \\
\hline gal & gallons & 3.785 & liters & L \\
\hline $\mathrm{ft}^{3}$ & cubic feet & 0.028 & cubic meters & $\mathrm{m}^{3}$ \\
\hline$y d^{3}$ & cubic yards & 0.765 & cubic meters & $\mathrm{m}^{3}$ \\
\hline \multicolumn{5}{|c|}{ NOTE: volumes greater than $1000 \mathrm{~L}$ shall be shown in $\mathrm{m}^{3}$} \\
\hline \multicolumn{5}{|c|}{ MASS } \\
\hline oz. & ounces & 28.35 & grams & g \\
\hline lb. & pounds & 0.454 & kilograms & $\mathrm{kg}$ \\
\hline $\mathbf{T}$ & Short tons (2000 lb.) & 0.907 & $\begin{array}{c}\text { megagrams } \\
\text { (or "metric ton") }\end{array}$ & Mg (or "t") \\
\hline \multicolumn{5}{|c|}{ TEMPERATURE (exact degrees) } \\
\hline${ }^{\circ} \mathbf{F}$ & Fahrenheit & $\begin{array}{c}5(F-32) / 9 \\
\text { or }(F-32) / 1.8\end{array}$ & Celsius & ${ }^{\circ} \mathrm{C}$ \\
\hline
\end{tabular}


Technical Report Documentation

\begin{tabular}{|l|l|l|}
\hline $\begin{array}{l}\text { 1. Report No. } \\
\text { 2117-9060-02-C }\end{array}$ & 2. Government Accession No. & 3. Recipient's Catalog No. \\
\hline $\begin{array}{l}\text { 4. Title and Subtitle } \\
\text { Workforce Development and Succession Planning to } \\
\text { Prepare the Rural Transit Industry for the Future }\end{array}$ & $\begin{array}{l}\text { 5. Report Date } \\
\text { July } 2016\end{array}$ \\
\hline
\end{tabular}

6. Performing Organization Code

7. Author(s)

Del Peterson and Ted Rieck

Upper Great Plains Transportation Institute

North Dakota State University

Fargo ND

9. Performing Organization Name and Address

National Center for Transit Research

Center for Urban Transportation Research (CUTR)

University of South Florida

4202 East Fowler Avenue, CUT100

Tampa, FL 33620-5375

11. Contract or Grant No.

\section{Sponsoring Agency Name and Address}

Research and Innovative Technology Administration

U.S. Department of Transportation

Mail Code RDT-30, 1200 New Jersey Ave SE, Room E33

Washington, DC 20590-0001

14. Sponsoring Agency Code

\section{Supplementary Notes}

\section{Abstract}

As America's transportation workforce continues to age, there is an increased need to invest in workforce development to combat the impending retirement tsunami. This is especially true within the small urban and rural transit industry. A literature review showed that 63 percent of U.S. transit workers are 45 years of age or older, and that significant job growth will occur during the next 10 years in both urban and rural communities. A national survey of rural transit managers was conducted to determine current workforce development practices as well as succession planning procedures. Viable responses were received from 160 agencies in 40 states. The majority of transit agency managers responding to the survey have been employed by their agency for more than 15 years while $75 \%$ of total respondents were 50 years of age or older. One-third of respondents indicated they plan to retire within the next 5 years while only $15 \%$ have any viable succession plan in place to combat such high management turnover. Details of succession plans varied considerably. Many respondents mentioned mentoring and one-on-one training as succession plan examples while others have current staff members designated to work with incoming management to familiarize them with agency rules and processes. Also concerning was that only $40 \%$ of respondents indicated having any type of employee recognition program in place. To improve employee morale and advancement opportunities from within, transit agencies must take the time to develop feasible succession plans and make an effort to reward employees for outstanding performance. 17. Key Words

Workforce development, rural transit, transit workers 18. Distribution Statement

No restrictions

\begin{tabular}{l|l}
$\begin{array}{l}\text { 19. Security Classification } \\
\text { (of this report) }\end{array}$ & $\begin{array}{l}\text { 20. Security Classification } \\
\text { (of this page) }\end{array}$ \\
Unclassified & Unclassified \\
\hline
\end{tabular}

21. No. of Pages

39
22. Price 


\section{TABLE OF CONTENTS}

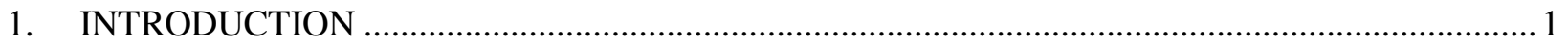

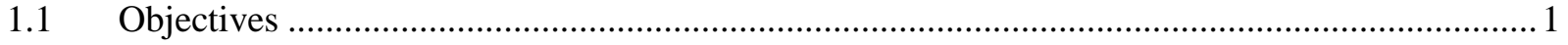

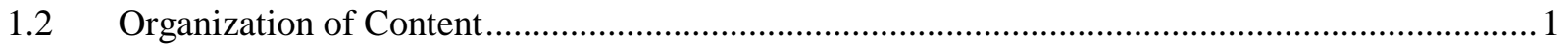

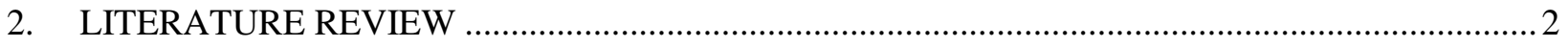

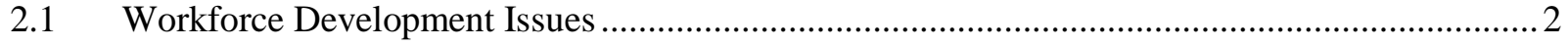

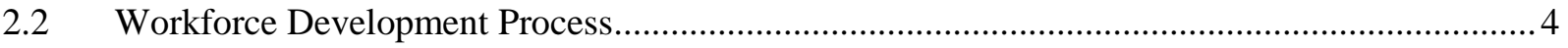

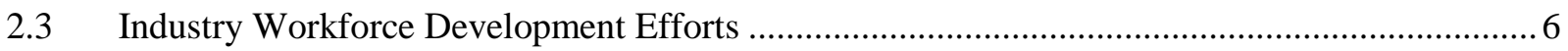

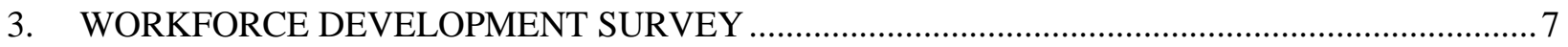

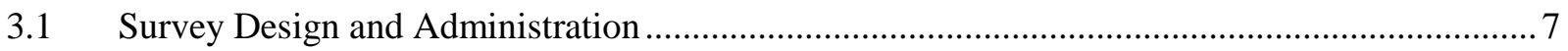

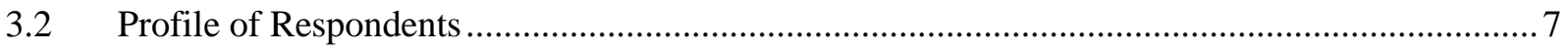

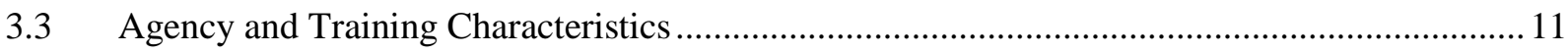

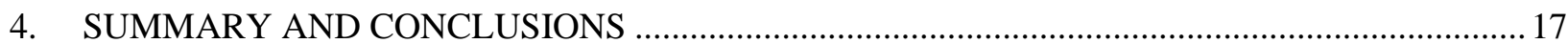

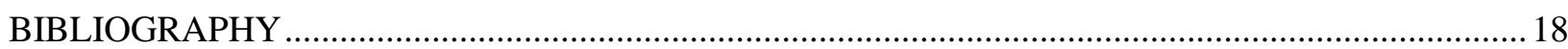

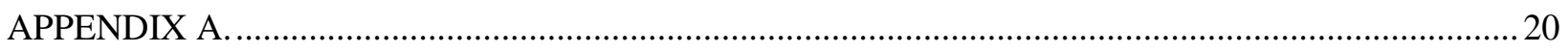

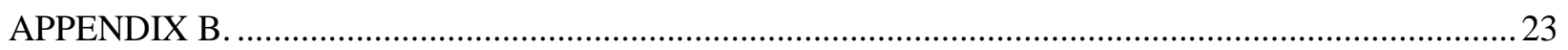




\section{LIST OF FIGURES}

Figure 2.1 Projected Transit Net Job Growth Rates by State (U.S. DOE 2015)..................... 4

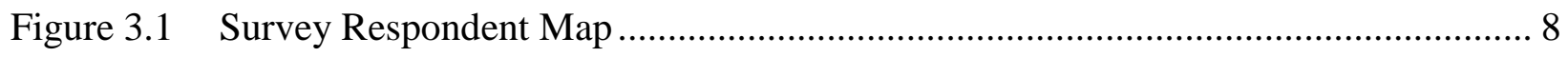

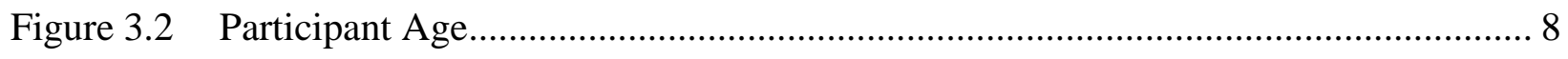

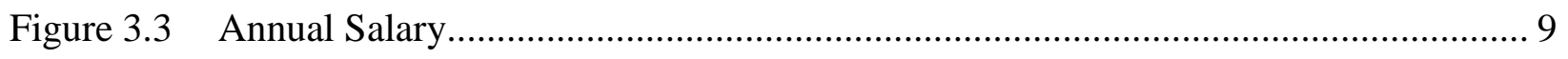

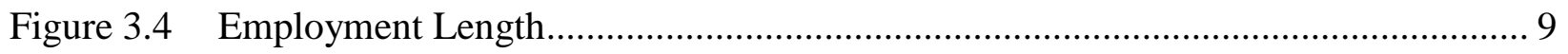

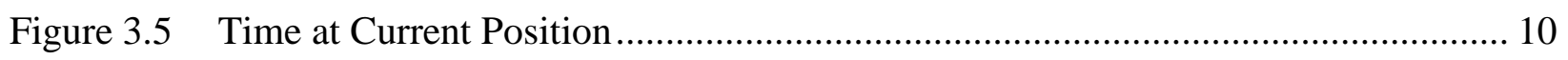

Figure 3.6 Positions Held Within Agency..................................................................... 10

Figure 3.7 Years Before Planned Retirement........................................................... 10

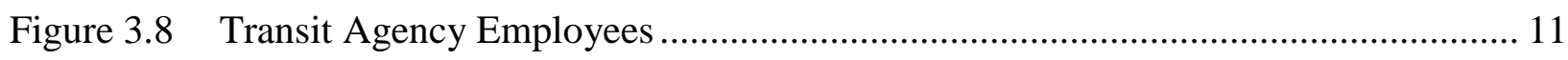

Figure 3.9 Trainings Available for Transit Managers ..................................................... 11

Figure 3.10 Training Attendees During Last 5 Years ........................................................ 12

Figure 3.11 Trainings Attended Throughout the Past 5 Years ............................................. 12

Figure 3.12 Trainings Beneficial to Your Job ................................................................ 13

Figure 3.13 Available Trainings that Managers Would Like to Take but Have Not ................ 13

Figure 3.14 Reasons for not Taking Trainings ............................................................ 14

Figure 3.15 Beneficial Workforce Development Trainings for Promotion ............................ 14

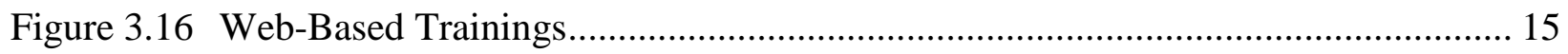

Figure 3.17 Agencies with Reward Recognition Programs .............................................. 15

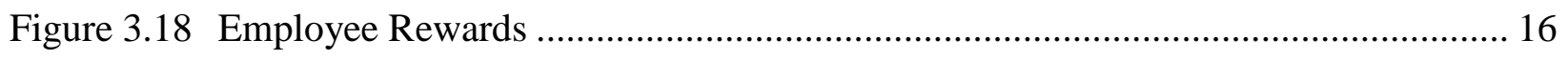

Figure 3.19 Agencies with Succession Plans ................................................................ 16 


\section{Acknowledgements}

The authors thank all of the small urban and rural transit managers who took time out of their busy schedules to complete the survey. This report would not have been possible without their input. Funding for this study was provided by the United States Department of Transportation through the National Center for Transit Research within the Center for Urban Transportation Research at the University of South Florida. The Small Urban and Rural Transit Center within the Upper Great Plains Transportation Institute at North Dakota State University conducted the research. 


\section{ABSTRACT}

As America's transportation workforce continues to age, there is an increased need to invest in workforce development to combat the impending retirement tsunami. This is especially true within the small urban and rural transit industry. A literature review showed that 63 percent of U.S. transit workers are 45 years of age or older, and that significant job growth will occur during the next 10 years in both urban and rural communities.

A national survey of rural transit managers was conducted to determine current workforce development practices as well as succession planning procedures. Viable responses were received from 160 agencies in 40 states. The majority of transit agency managers responding to the survey have been employed by their agency for more than 15 years while $75 \%$ of total respondents were 50 years of age or older. One-third of respondents indicated they plan to retire within the next 5 years while only $15 \%$ have any viable succession plan in place to combat such high management turnover.

Details of succession plans varied considerably. Many respondents mentioned mentoring and one-on-one training as succession plan examples while others have current staff members designated to work with incoming management to familiarize them with agency rules and processes. Also concerning was that only $40 \%$ of respondents indicated having any type of employee recognition program in place. To improve employee morale and advancement opportunities from within, transit agencies must take the time to develop feasible succession plans and make an effort to reward employees for outstanding performance. 


\section{Potential Training Opportunities}

A number of national organizations provide training for rural transit agencies. Trainings range from manager-level education to opportunities for drivers and front-line personnel. Many also provide inperson as well as web-based training options. Following is a list of many potential organizations that can provide training options for agencies. These include:

- American Public Transportation Association (APTA)

- Center for Transportation e-Learning (CTeL)

- Community Transportation Association of America (CTAA)

- Easter Seals Project Action (ESPA)

- Federal Transit Administration (FTA)

- National and State Level Rural Transit Assistance Program (RTAP)

- National Transit Institute (NTI)

- Small Urban and Rural Transit Center (SURTC)

Numerous training opportunities exist on both state and local levels as well. Links were provided courtesy of APTA and CTAA that can be used to gain more information regarding local transit trainings that may be of interest to rural transit agencies. Many of these resources include state transit associations as well as state DOTs.

\section{Summary and Conclusions}

As America's transportation workforce continues to age, there is an increased need to invest in workforce development to address the impending retirement tsunami. This is especially true within the small urban and rural transit industry. Literature review findings showed that 63 percent of U.S. transit workers are 45 years of age or older, and that significant job growth will occur during the next 10 years in both urban and rural communities (U.S. Department of Education 2015).

Details of succession plans among survey respondents varied considerably. Many respondents mentioned mentoring and one-on-one training as succession plan examples while others have current staff members designated to work with incoming management to familiarize them with agency rules and processes. Also concerning was that only $40 \%$ of respondents indicated having any type of employee recognition program in place. To improve employee morale and advancement opportunities from within, transit agencies must take the time to develop feasible succession plans and make an effort to reward employees for outstanding performance.

Training opportunity findings for both national and local levels focused on various topics from transit principles to emergency and human resource management. Overviews and training opportunities were emphasized with links to potential training sites listed for each organization. Focusing on potential webbased trainings may be practical for many rural transit agencies. These trainings are usually less costly and time consuming when factoring in the need for travel to traditional in-person classroom training. Survey results showed that inexperienced managers required transit principles training while training for more experienced managers should focus on leadership, business plan development, and emergency management. Transit principles, human resource management, and emergency management were found to be helpful trainings for employees seeking internal advancement within an agency. 
The successful recruitment and training of workers who will be responsible for all aspects of transit operations is both critical and timely. Steps must be taken to ensure that proper planning ensures the future viability of the industry. Increased investments in employee development now will yield a future public transportation workforce with the knowledge and ability to serve rural America for generations to come. 


\section{INTRODUCTION}

For more than a decade, succession planning involving the recruitment, development, and retention of transit managers has been the subject of numerous research studies. Some of these studies have focused on rural and small urban areas and have included case studies of related transit systems. Despite the aging of upper management in the rural transit industry, little has been done to prepare local systems for the inevitable departure of many baby boomer managers. Applied research must be undertaken to provide a smooth transition for the public transportation industry as it looks to the future.

Note that many rural transit systems began as adjuncts to local senior meal programs and eventually became conjunctive elderly and handicapped transit programs. This cooperative relationship still exists today, often with the same managers who were onboard at the time the programs were created. These managers have decades of experience and are responsible for, not only transit operations, but also for functions such as operating local senior centers and running local senior meals programs. Related organizational structures are commonly flat and managers dedicate only a small percentage of their time to transit activities.

Managerial changes will ultimately occur in all of these operations - some will be planned, but others may happen quickly and be unplanned and unannounced. Providing long-term and uninterrupted personal mobility services will depend on prior workforce development and succession planning to develop future leaders within each organization. This is especially true given the complexity of managing transit services (operational planning, human resource management, grant writing, grant management, etc.), the rural settings that many of these systems operate in, and, in many instances, the lack of a qualified pool of replacement personnel. These organizational structures and difficulties related to succession planning, recruitment, and staff development are not unique to specific paratransit agencies. In fact, they are common in rural states throughout the country.

\subsection{Objectives}

The objectives of this research were to address perceived workforce development and succession planning difficulties within the rural public transit industry. This study included a literature review providing insight regarding the current state of the existing transit industry structure along with related workforce development and succession plans. A nationwide survey was also conducted to determine current workforce development practices as well as succession planning procedures. Applicable resources for rural transit agencies to consider when developing a training program were also included.

\subsection{Organization of Content}

The study begins with a literature review including research papers and other applicable materials addressing workforce development issues from multiple perspectives. Following the literature review are results from a nationwide survey conducted within the rural transit agency industry. Agency characteristics, manager traits, workforce training practices, and succession planning techniques are all included within this section. Finally, an overall summary concludes the study with recommendations based on research findings. The appendix includes a collection of potential training resources from both a national and local level and the workforce development survey instrument. 


\section{LITERATURE REVIEW}

\subsection{Workforce Development Issues}

Workforce development has been a concern of the transit industry for some time. In 2001, with the support of the American Public Transit Association (APTA), the Transit Cooperative Research Program (TCRP) issued a self-described scoping study to define the industry's workforce development challenges (Vogel 2001). The scoping study viewed workforce broadly, including front-line as well as management personnel. "Changes in technology and in demographics," along with industry growth, were among several factors driving workforce issues. The scoping study consisted of two main parts: a series of listening sessions and key leader interviews. The listening sessions were part of various APTA conferences and meetings during 2001. The sessions solicited opinions regarding workforce issues. Following the listening sessions, structured interviews with 31 transit leaders revealed a number of key issues. The transit leaders represented a cross section of large- and medium-sized agencies, unions, and private firms. Among the issues identified in the interviews included: an aging workforce, weak succession planning for top positions, and recruitment challenges for specialty areas such as administration, engineering, IT, and marketing. These and other workforce issues affected the entire industry.

In 2010, APTA issued a report from its "Blue Ribbon Panel on Workforce Development." The BlueRibbon panel, as was seen in 2001, sought “...industry input (including listening and program sessions at APTA conferences and meetings; participating in meetings/conferences with members, federal partners, union representatives, university transportation centers, education and training providers, other stakeholders, etc." The panel made 32 recommendations grouped into six core areas including: Legislative, Image and Branding, Higher Education, Youth Outreach and Awareness, Partnership and Collaboration, and Performance Measures/Return on Investment. Each core area was assigned a chairperson with a timeline to address its assigned recommendations. Some of the recommendations included showing transit as a high-growth industry, increasing college internship opportunities, and developing performance-monitoring metrics.

Also in 2010, APTA issued its "Preliminary Skill Development and Training Needs Report." The report presented information from a survey of people employed by selected APTA members. Of 258 responses, 219 were agency employees and 39 were employees with business, non-profit, or university members. The survey solicited responses regarding the employee's age, expected remaining tenure at the organization, and their position within the organization among other things. According to the report, however, the survey suffered from "... self-selection bias in who decided to respond, we cannot be certain that this is a truly random sample." The data from the survey, therefore, is mainly anecdotal. Even so, the responses mirror other views that there is an emerging and troublesome wave of retirements and that APTA should focus more on workforce development (APTA 2010).

In 2012, APTA continued the work of the 2010 Blue Ribbon Panel by issuing a report from its Workforce Development Task Force. The task force recognized "... the challenges the public transportation industry faces, as an unprecedented wave of retirements and an abundant, irreplaceable loss of industry knowledge and experience..." and made a "call to action" (APTA 2012). APTA called for formalizing workforce development efforts by improving funding for transit, assigning one of APTA's education affiliates to take charge of workforce development, and to work more closely with military veterans. Further, APTA opened itself to nontraditional partnerships, empowering mid-level managers, and involving the private sector. 
TCRP Synthesis 71-Paratransit Manager's Skills, Qualifications, and Needs (Potts 2007) presented information about the desired and actual skills and qualifications of paratransit managers. For the purposes of their report, the authors defined paratransit as "the full range of demand-responsive services, including Americans with Disabilities Act (ADA)-complementary, general public dial-a-ride, and human service transportation." They also defined, again for the purposes of the synthesis, a paratransit manager as "...the highest-ranking person in the agency with direct responsibility for paratransit service delivery." The synthesis consisted of a survey of 59 agencies with paratransit operations. Nine of the respondents were rural systems and the remaining 49 were urban. The surveys asked for current job requirements as well as the actual job qualifications of the incumbents. Job requirements such as education, experience, special skills, as well as starting salaries were compared with the actual qualifications of the responding paratransit manager. For example, about 66 percent of the respondents required a college degree for their paratransit managers. However, 69 percent had a college degree or higher with 50 percent having a graduate degree. Of the agencies, 75 percent required five or less years of experience while 42 percent of the managers had 10 or more years' experience. The survey also asked the managers and their CEOs the top skills most important to the job. Among the most desirable skills were media relations, computerized scheduling, and safe driving practices. However, in the last five years, most managers received management and supervisory training and prevention of sexual harassment.

The U.S. Department of Education (2015) recently published its data report of future transportation needs. It forecasted that transportation is projected to add 417,000 net jobs from 2012 to 2022 because of industry growth, and that 48 U.S. states, with the exception of Kentucky and Vermont, will experience job growth during this period. The fastest growth will occur on the West Coast, the Gulf Coast, the MidAtlantic Region, and throughout the Midwest and within several Mountain States. The highest percentage of these new jobs will be in transit and ground passenger transportation.

Specific to transit, the study showed that 63 percent of transit workers are 45 years old or older, and that retirement will have a significant impact on the future workforce. Significant net job growth in transit will occur from 2012-2022 in many states, including largely rural states such as North Dakota, South Dakota, Wyoming, Nebraska, Iowa, Arkansas, and Louisiana, among others. Figure 2.1 illustrates these projected net job growth rates (U.S. Department of Education 2015). 


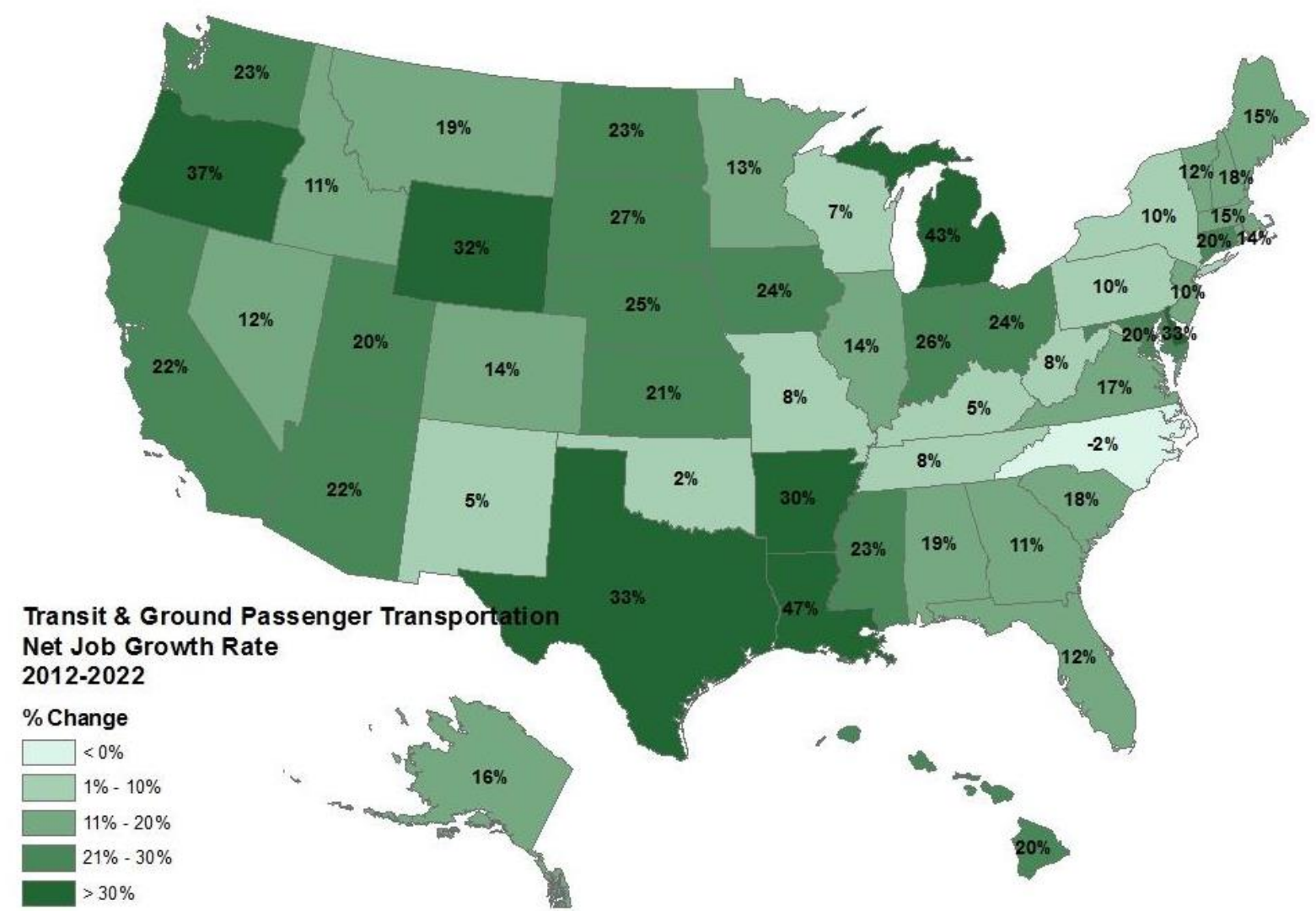

Figure 2.1 Projected Transit Net Job Growth Rates by State (U.S. DOE 2015)

\subsection{Workforce Development Process}

Two TCRP publications addressed the workforce development process. In addition, a pair of articles from Forbes magazine discussed succession planning. First, TCRP 127-Employee Compensation Guidelines for Transit Providers in Rural and Small Urban Areas released in 2008 described how to determine appropriate compensation for employees as part of attracting and retaining employees. The second publication was TCRP 139-Guidebook for Recruiting, Developing, and Retaining Transit Managers for Fixed-Route Bus and Paratransit Systems published in 2010 which systematically described the management of major phases of the "employment cycle." In 2009, Forbes presented a two-part series on succession planning for top-level positions.

TCRP 127-Employee Compensation Guidelines for Transit Providers in Rural and Small Urban Areas did two things: first, it described the process for determining compensation levels for employees and, second, described managing the "employment cycle" from job development to recruitment to hiring to retention (KFH Group, Inc. 2008).

The report defined compensation as the total of wages and benefits paid to an employee where employees cover the gamut from front-line to senior management personnel. The report indicated that variables such as organizational characteristics (e.g., whether a multipurpose nonprofit, municipal department, or independent authority), service mix (e.g., fixed route and demand response), size of the operation, and employee characteristics (e.g., paid versus volunteer) greatly influence compensation decisions. The 
project administered surveys to 360 rural and small urban systems, or almost $20 \%$ of the systems believed to be in operation at the time. In addition to collecting basic system characteristics, the survey obtained data regarding staffing features as well as wages and benefits. The surveys revealed that 72 percent of the respondents directly operated service with 37 percent operated as a department of either a city or county government. Of the agencies, 65 percent provided benefits only to full-time employees while 18 percent provided benefits to all employees. The questionnaire and detailed survey results were contained in the appendices of the full report.

TCRP 139-Guidebook for Recruiting, Developing, and Retaining Transit Managers for Fixed-Route Bus and Paratransit Systems was a "how-to" manual for managing the employment cycle; i.e., recruitment, training and development, and retention. The manual included recommended practices as well as short examples drawn from transit operations across the country. Each main section illustrated recommended practices with "pros and cons." For example, the recruitment section discussed the use of national transittargeted publications, such as APTA's Passenger Transport, in recruiting for personnel. The advantage of using a national publication was their far reach. A disadvantage could be their cost. The manual suggested using national publications for jobs with limited numbers of potential local candidates. Bus driving positions might not be an appropriate job category for national publications while senior managers would likely be. (Anderson et al. 2010).

The manual discusses "workforce development" which included training. Training was considered a subset of development along with job coaching and mentoring. The manual also recognized that funding development activities can be challenging, especially during tight fiscal periods. Typically, development budgets are among the first to be reduced during lean periods. To address this situation, the authors suggested using a variety of sources such as industry materials, funding from the Rural Transit Assistance Program (RTAP), or web-based programs.

The manual also has a section on "succession planning" as part of workforce development. "Succession planning is the process of identifying and preparing qualified employees through mentoring, coaching, training, and job rotation opportunities to replace staff in key management positions as these positions become vacant." (Anderson et al. 2010).

Finally, the manual addressed employee retention. The authors indicated that voluntary employee turnover was related to job satisfaction. Providing flexible work schedules, recognition programs, and building a "culture of ownership" were among the strategies presented to reinforce and increase job satisfaction.

Stephen Miles wrote two companion articles for Forbes on succession planning aimed at private, forprofit businesses. The first, "Succession Planning: How Everyone Does It Wrong," illustrated where firms fell short in this vital activity. The second article provided guidance on how to create an effective succession planning process.

Miles contended that many firms view succession planning as merely "window dressing" or a box to check. Often, such plans typically and exclusively focus on the Chief Executive Officer (CEO). Further, there was a tendency among the boards of private firms to look outside the organization for new CEOs and not consider internal candidates. Compounding this deficiency are these "myths" about CEO successors commonly held by boards: outside candidates are more exciting and promising than internal candidates; successor has to be ready "now;" and succession planning should not exclude other "C" level personnel, not just focusing only on the CEO (Miles July 30, 2009). 
In his follow-up article (Miles July 31, 2009), Miles recommended that succession planning:

- Engage stakeholders going beyond the current CEO and human resources simply presenting a plan to the board.

- Identify and assess internal candidates.

- Conduct a "stress test" to see who would step into CEO role in an emergency. Look at candidates who are ready in the short term as well as identify people who could be ready with preparation in the longer term.

- "On-board the successor" described how to help the new person transition into their role. Too often boards use a "sink or swim" approach that can lead to unfortunate results.

\subsection{Industry Workforce Development Efforts}

In 2011, the Federal Transit Administration (FTA) began awarding Innovative Workforce Development Grants "providing funding to transit agencies and other entities with innovative solutions to pressing workforce development issues." (FTA, Federal Register 2012). For 2011 and 2012, FTA awarded 12 grants and 17 grants respectively. In 2011, the grants totaled $\$ 3$ million (averaging $\$ 250,000$ per grant) with five projects targeting management personnel, two addressing front-line staff, and five a combination of the two (FTA 2011). In 2012, $\$ 7$ million (averaging $\$ 411,765$ per grant) funded one project related to management, nine for front-line, six for a combination, and one more for office personnel (FTA 2012). ${ }^{1}$

The city of Charlotte, NC, has put into practice a shared leadership learning program focusing on mentoring in the workplace. Although Charlotte, NC, is a large urban area, many of its program ideas are scalable to more rural communities. The purpose of their program is to provide support and improve the development of current employees by teaming them with leadership personnel outside their area of expertise. Specifically, they are focusing on improving five workforce development tasks. These include:

1. Increase employee professional and personal skills based on individual needs.

2. Help employees feel more included within the organization.

3. Retain and develop future leaders.

4. Develop more community within the organization as people from various departments work together.

5. Help leaders feel valued for their experience to motivate future work tasks.

(City of Charlotte 2016)

To more precisely pair mentors with potential mentees, both parties complete a self-assessment pinpointing their preferred work styles. Mentees also complete a short questionnaire indicating what characteristics they desire in a mentor. A selection committee matches the two based on testing results and survey findings. Once the pairs have been decided, both mentors and mentees attend an orientation session to learn more specifics regarding the program. Remaining sessions focus on networking with other participants, learning about selected leadership experiences from various mentors, and other relevant topics. Overall, the program has been very successful in training less-experienced employees and improving morale throughout the entire city workforce (City of Charlotte 2016).

\footnotetext{
${ }^{1}$ The classifications of the grants were solely based on the grant's brief description as presented by FTA.
} 


\section{WORKFORCE DEVELOPMENT SURVEY}

\subsection{Survey Design and Administration}

The Small Urban and Rural Transit Center (SURTC) designed online surveys to distribute to transit agency directors. Surveys contained questions regarding current workforce development practices as well as anticipated needs regarding training and succession planning. A copy of the survey is found in Appendix A. The survey was distributed nationwide via email to agencies in small urban and rural areas. An email list containing nearly 800 valid email addresses was used along with individual transit agency contacts. The email list was specific to those agencies receiving 5311 formula grant federal funding. These grants are distributed to states for the purpose of supporting population areas of fewer than 50,000. The goals of the program are to:

- enhance the access of people in nonurbanized areas to everyday services,

- assist maintaining nonurbanized public transportation systems,

- encourage the efficient use of transportation funds through the coordination of services,

- assist with intercity bus transportation, and

- $\quad$ provide for private transportation providers in nonurbanized areas.

(Federal Transit Administration 2016).

A total of 137 usable surveys were received from the email list yielding an almost 20\% response rate. Another 23 surveys were received from other individual transit agency contacts, providing a total of 160 viable surveys. No incentive was given to potential respondents for completing any questions.

\subsection{Profile of Respondents}

Survey participants represented 40 U.S. states (Figure 3.1). Ten states had five or more respondents while the other 30 had between one and four, respectively. Figure 3.1 also shows that the distribution of states represented most of the county equally. There was similar participation from northeastern and southeastern states. Only two southeastern and four northeastern states were not represented. One midwestern state was unrepresented while three states from the southwest and northwest had no respondents. Iowa had the most respondents with nine, and California and Texas had the second-most with seven each. 


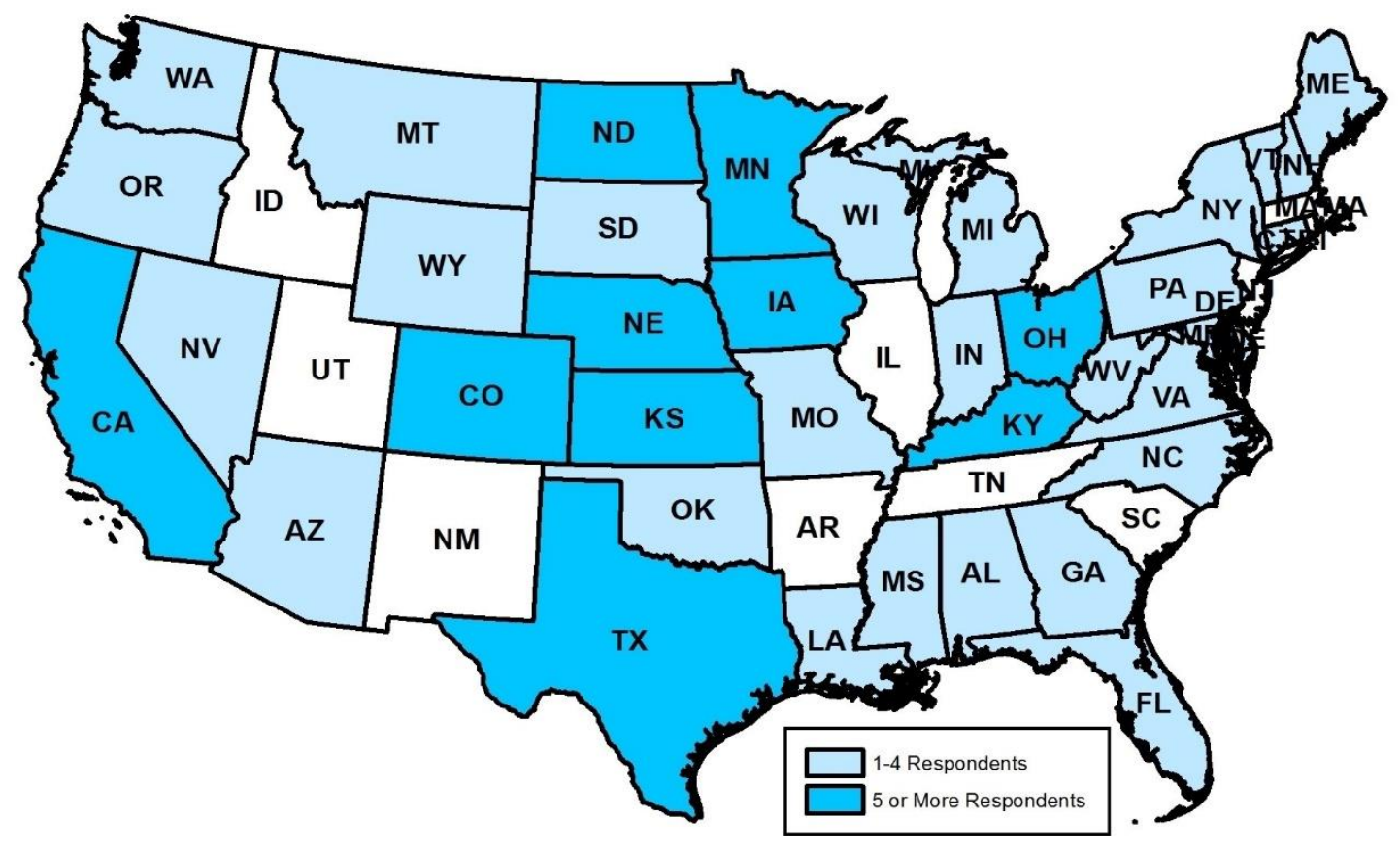

Figure 3.1 Survey Respondent Map

Survey respondents varied significantly in age with $75 \%$ indicating that they were age 50 or older (Figure 3.2). Nearly $7 \%$ reported being between 30 and 39 years old while $16 \%$ indicated that they were in their $40 \mathrm{~s}$. No one in their 20 s completed the survey.

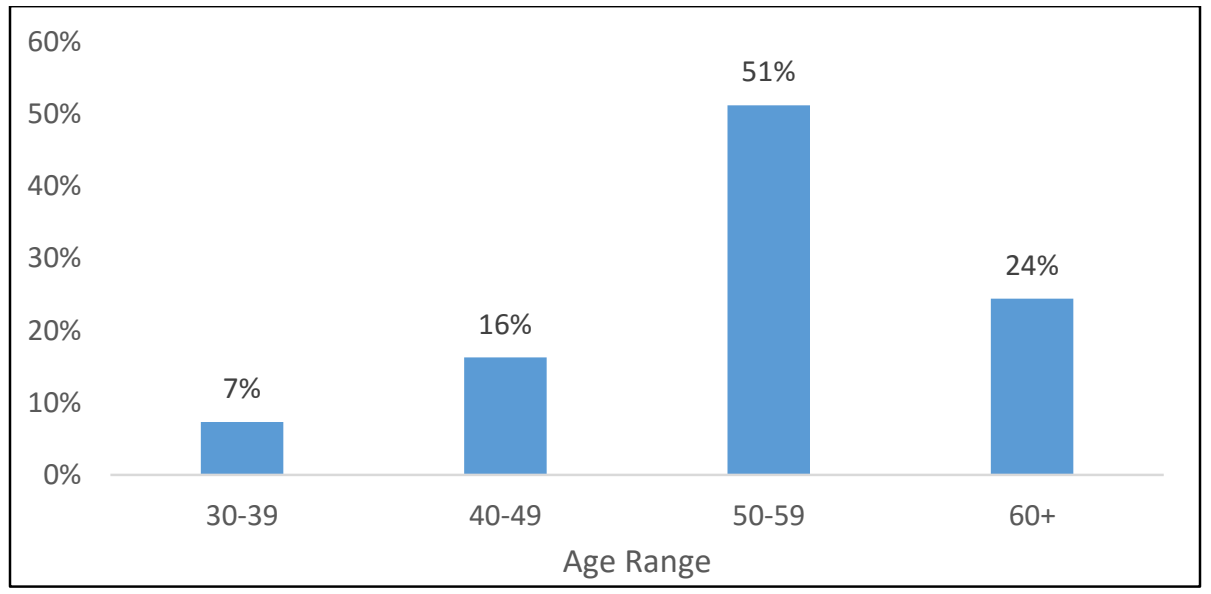

Figure 3.2 Participant Age 
Incomes also varied widely among survey participants. Figure 3.3 shows that nearly $25 \%$ of respondents reported their annual salary to be less than $\$ 50,000$, while $20 \%$ said their annual salary is greater than $\$ 80,000$. However, the majority, indicated their annual salary was between $\$ 50,000$ and $\$ 80,000$.

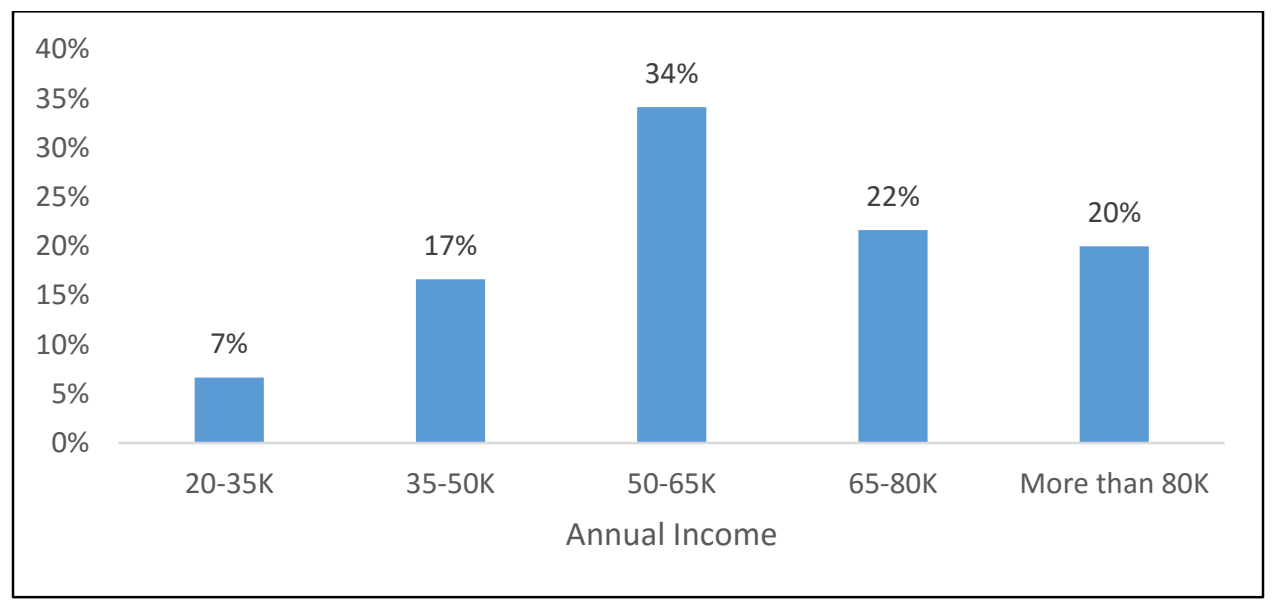

Figure 3.3 Annual Salary

Transit managers were then asked how long they have been employed by the current transit agency. Only $15 \%$ indicated they had been with their current employer for fewer than 5 years (Figure 3.4). Nearly 50\% of respondents have worked at their current agency for longer than 16 years while about one-third of the managers surveyed have been with their current employer between 6 and 15 years.

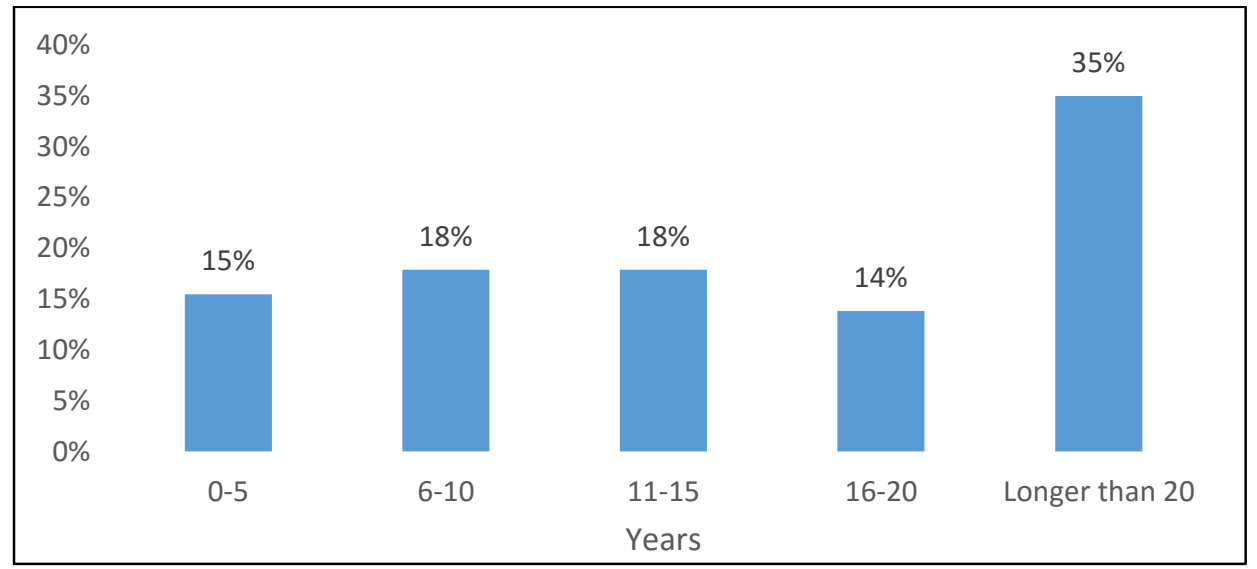

Figure 3.4 Employment Length with Current Employer

A majority of transit managers reported holding their current position for longer than 10 years. More than $30 \%$ indicated that they have held their current position for more than 15 years and $16 \%$ for more than 20 years (Figure 3.5). Nearly 45\% responded that they have held their current position for less than 10 years with nearly $30 \%$ of managers holding their position for less than 5 years. Almost half of the current managers also indicated that they have held multiple positions within the same agency (Figure 3.6). Of the respondents, 16 percent have held 3 or more positions while $55 \%$ have held only their current position within the agency. 


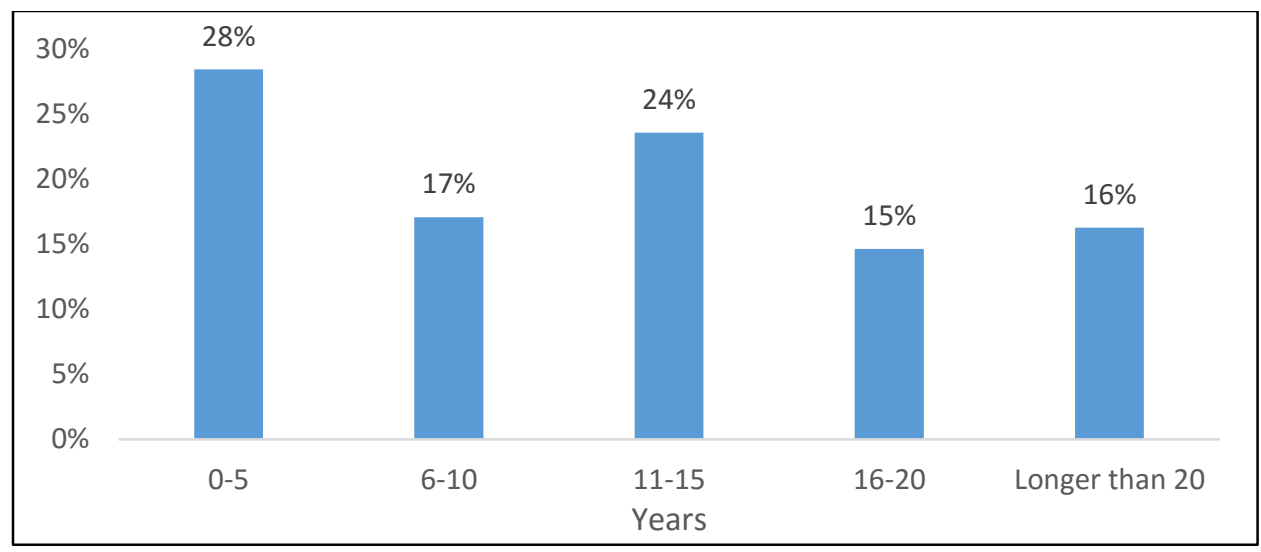

Figure 3.5 Time at Current Position

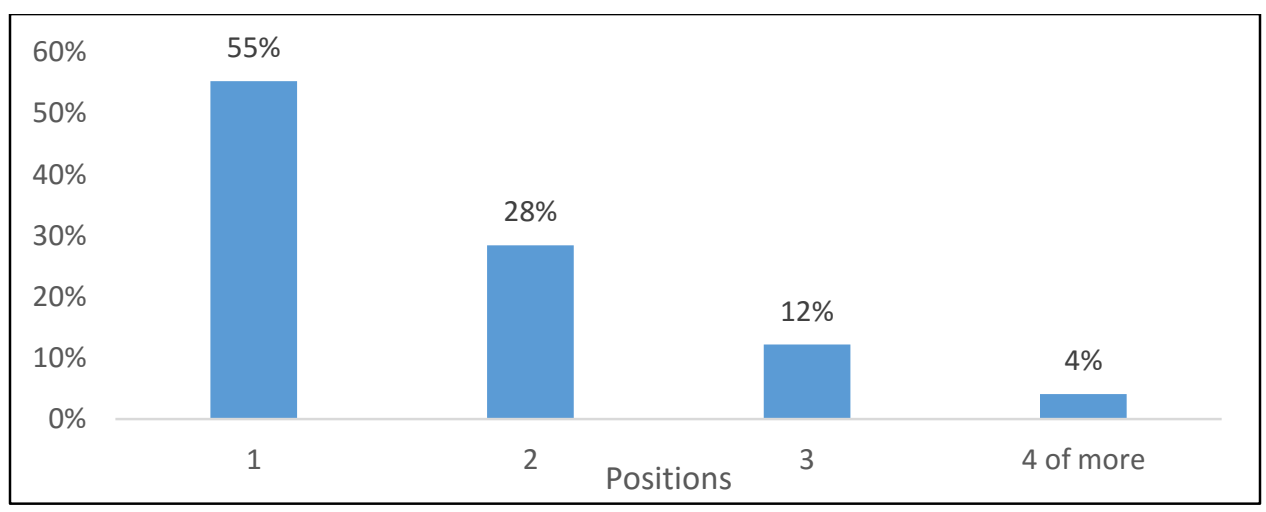

Figure 3.6 Positions Held Within Agency

Finally, transit managers were asked how much longer they anticipated working before retirement (Figure 3.7). More than $30 \%$ of participants indicated they will be working less than 5 years before they retire while nearly $40 \%$ indicated they will be working more than 10 years before retirement. Almost $30 \%$ of respondents will be working another 6 to 10 years before retirement, according to survey results.

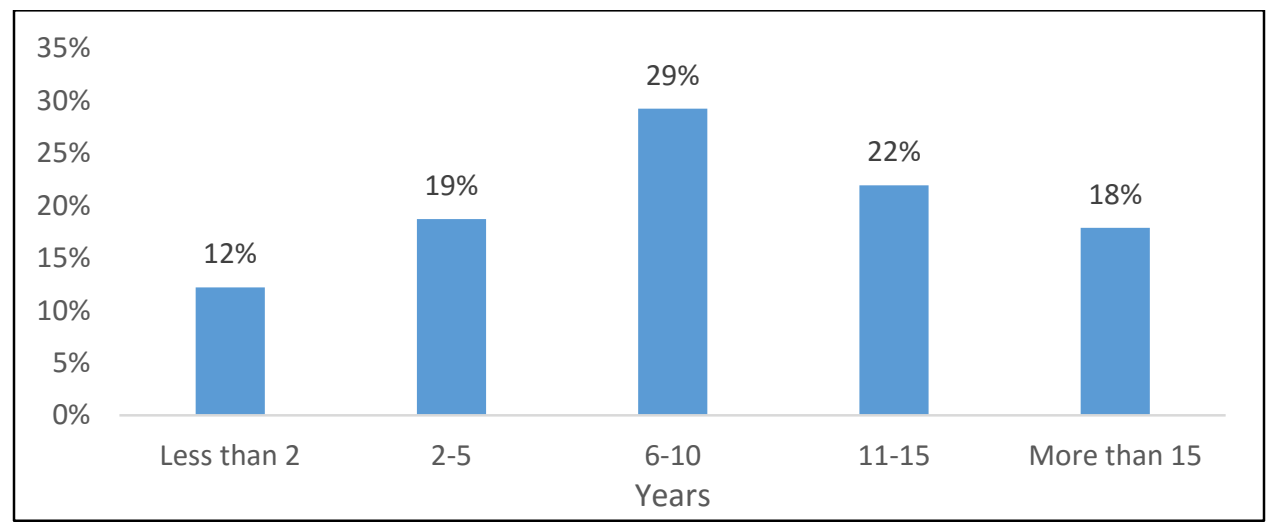

Figure 3.7 Years Before Planned Retirement 


\subsection{Agency and Training Characteristics}

Survey participants were asked about the number of people employed at their transit agency (Figure 3.8). This included part-time employees, but not contracted employees. One-third of respondents indicated that more than 30 employees currently work at their agency while $18 \%$ reported having fewer than 6 employees. About $25 \%$ of the remaining managers indicated they have either between $6-15$ or 16-30 employees working at their agencies.

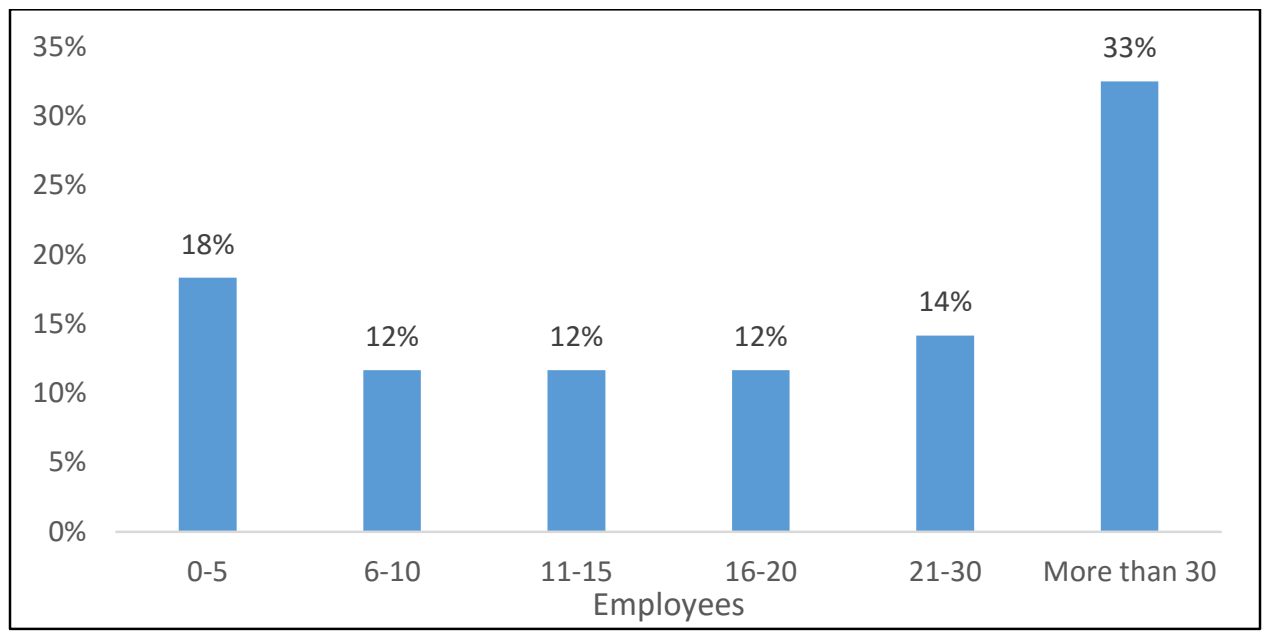

Figure 3.8 Transit Agency Employees

Respondents were then asked to indicate whether or not they were aware of certain available trainings (Figure 3.9). Nearly $40 \%$ of managers reported being aware of transit principles training while $26 \%$ indicated they were aware of available emergency management training. One-fourth of respondents are aware of human resource training, and $20 \%$ know that business plan training is offered to them. Finally, trainings dealing with local governments and cost/benefit analysis had an awareness level of lower than $20 \%$.

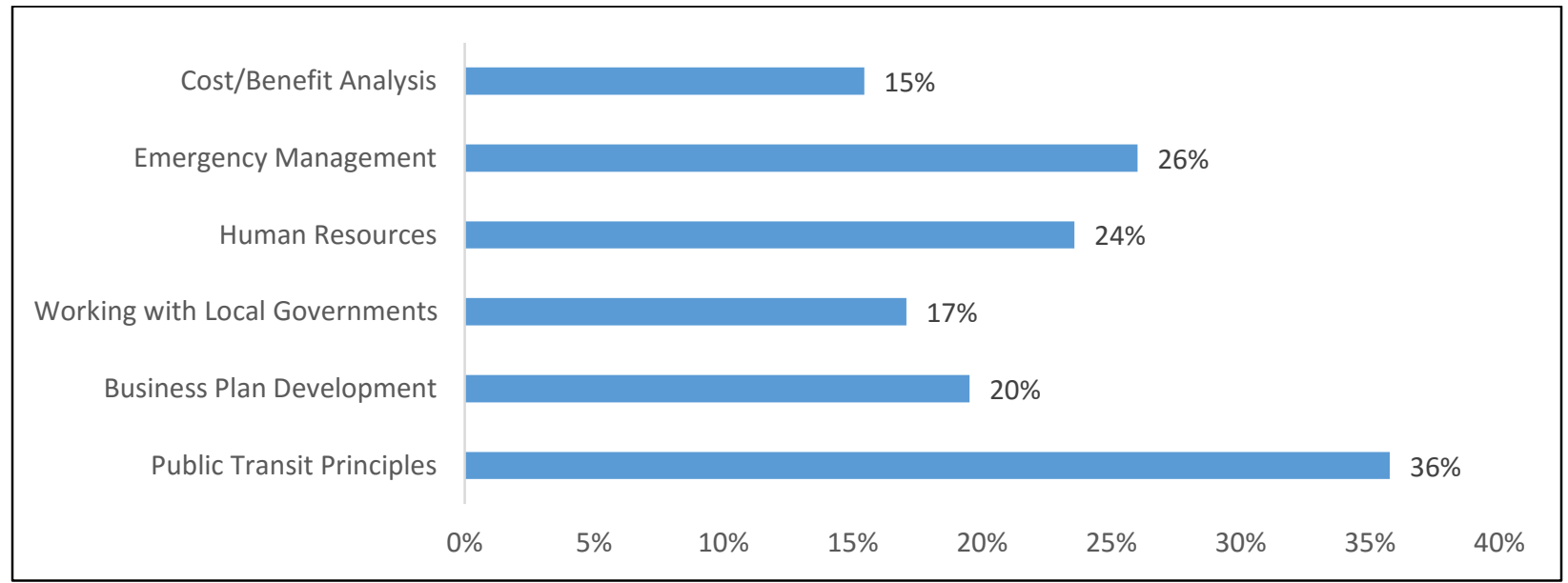

Figure 3.9 Awareness of Trainings Available for Transit Managers

Participants were then questioned regarding their attendance at trainings (Figure 3.10). Less than half indicated that they had attended some type of transit-manager-specific training during the past five years. Also, of respondents who indicated that they had attended training during the last five years, 35\% 
reported that they had only attended one or two trainings during that time frame (Figure 3.11). Nearly $50 \%$ of respondents who indicated that they had attended trainings attended between three and six trainings throughout the past five years while the remaining $17 \%$ have attended seven or more trainings during that time period.

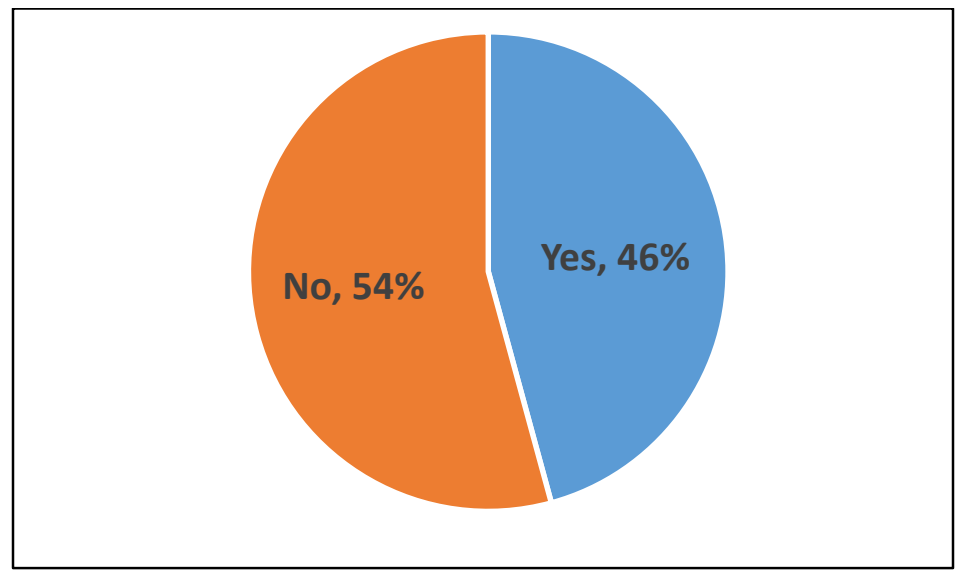

Figure 3.10 Training Attendees During Last Five Years

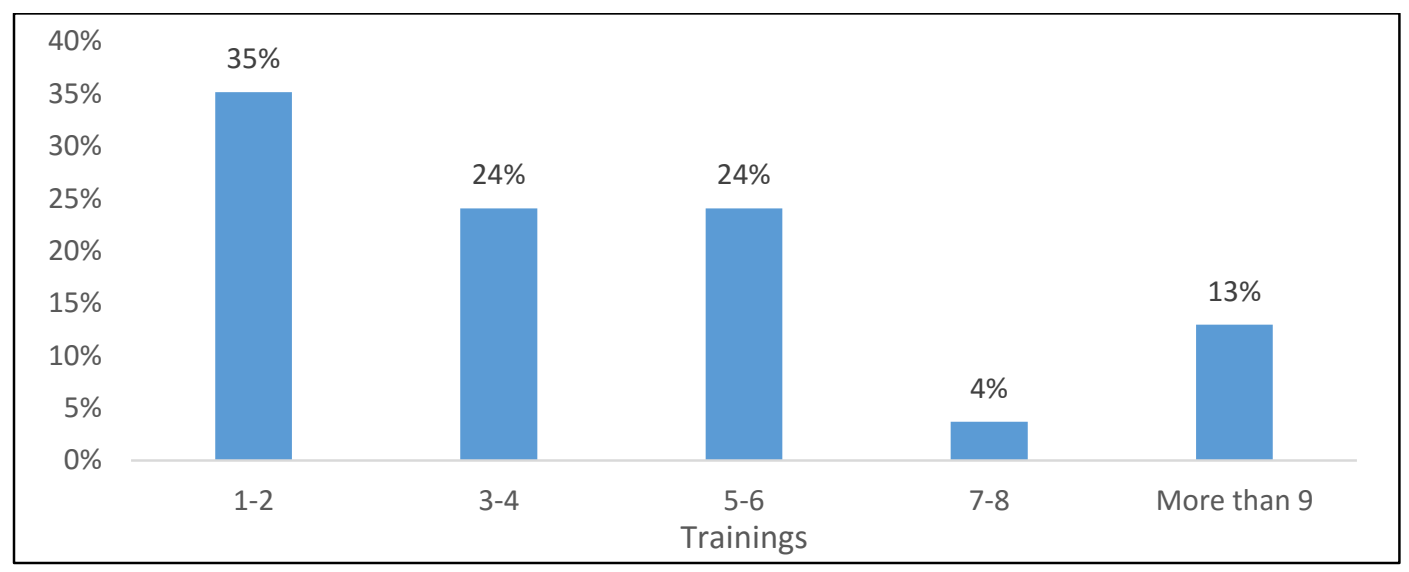

Figure 3.11 Trainings Attended Throughout the Past Five Years

The vast majority of managers surveyed believed that the trainings they've taken have been beneficial to their job (Figure 3.12). Mangers with more than 15 years of experience found leadership, business plan development, and emergency management most beneficial while managers with less than 10 years of experience found transit principles and cost/benefit analysis trainings most beneficial. Specifically, respondents indicated that the following trainings have been of the greatest benefit, in no specific order:

- Grant Writing

- Improving Transit Ridership

- Business Plan Development

- Human Resource Management

- Emergency Management

- Networking

- Leadership

- Harassment and Ethics

- Transit Principles 


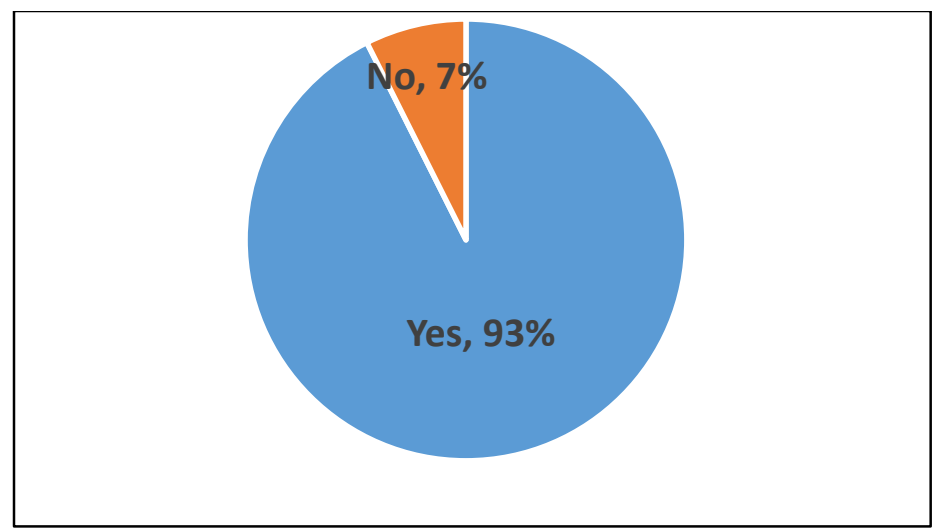

Figure 3.12 Trainings Beneficial to Your Job

Survey participants were then questioned about available trainings that they would like to take but have not (Figure 3.13). Almost half of respondents (44\%) indicated they would like to take cost/benefit analysis training, and $40 \%$ would like to take transit principles. The four other options, including emergency management, human resources, working with local governments, and business development training, were preferred by nearly $40 \%$ of managers as well.

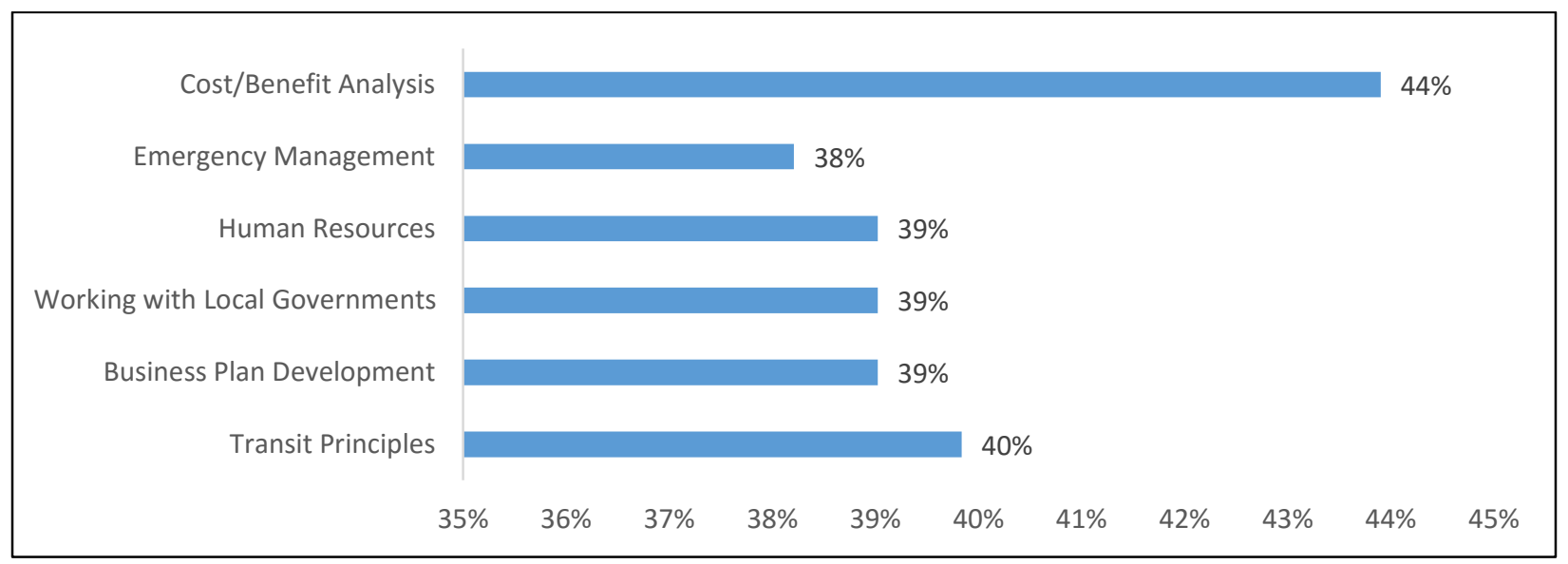

Figure 3.13 Available Trainings that Managers Would Like to Take but Have Not

Transit managers were then asked why they have not taken specific trainings (Figure 3.14). A lack of funding and time were the two main reasons for not taking trainings. Distance and scheduling conflicts were also mentioned by more than a third of respondents. Among managers from smaller agencies (15 employees or less) distance and not enough time were the biggest reasons for not attending trainings. Finally, trainings being too time consuming was cited by $12 \%$ of participants as a significant reason for not taking trainings. 


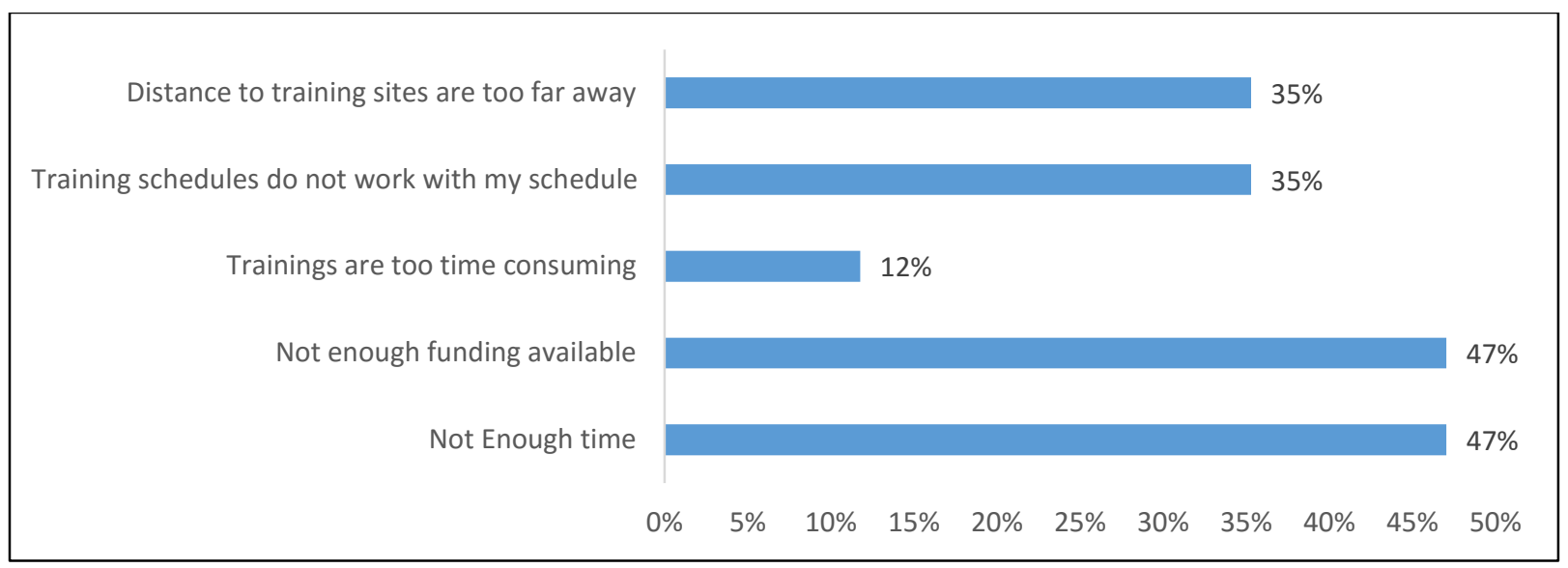

Figure 3.14 Reasons for not Taking Trainings

Survey participants were also questioned regarding training available for internal employees interested in promotion. A number responded that trainings are often available through the Community Transportation Association of American (CTAA) as well as the American Public Transportation Association (APTA). Some mentioned internal trainings are available in subject matter such as leadership, human resources, and business plan development. When asked specifically about the following trainings, (Figure 3.15), nearly half of respondents believed that training for employees in transit principles would be helpful while about a third felt that training in cost/benefit analysis, emergency management, and human resources would be useful as well. Trainings involving work with local governments and business plan development, although helpful, did not receive as much emphasis from survey participants as the previous topics mentioned. Also, managers with more than 20 years of experience responded that internal employees interested in promotion should focus on transit principles, human resources, and emergency management trainings.

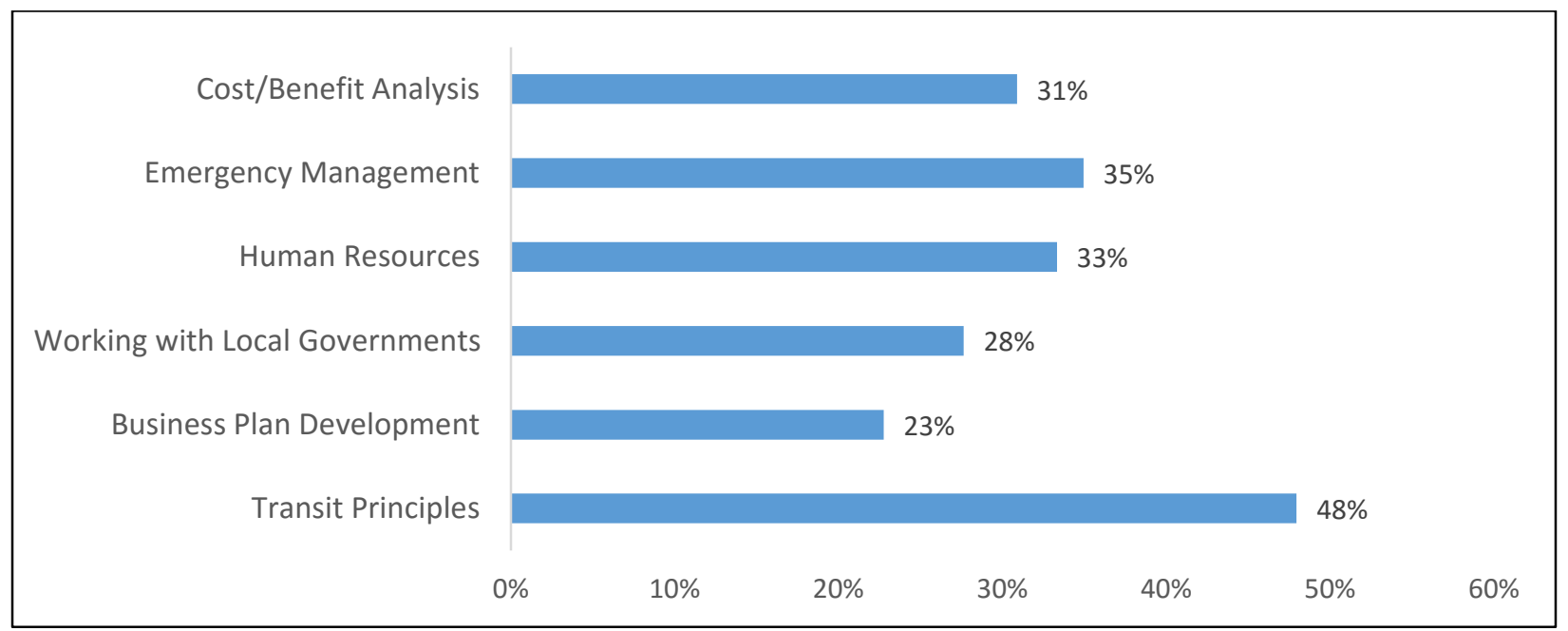

Figure 3.15 Beneficial Workforce Development Trainings for Promotion

Three-fourths of respondents have taken some form of training through a web-based platform according to survey findings (Figure 3.16). When asked specifically what topics were covered, transit managers indicated the following in no particular order:

- Americans with Disabilities Act Compliance

- Harassment and Ethics 
- Cultural Diversity

- Drug and Alcohol Awareness

- Federal Transit Administration Compliance

- Conflict Management

- Critical Thinking

- Grant Funding

- Microsoft Office

- Web Page Design

- Vehicle Procurement

- Generational Communication

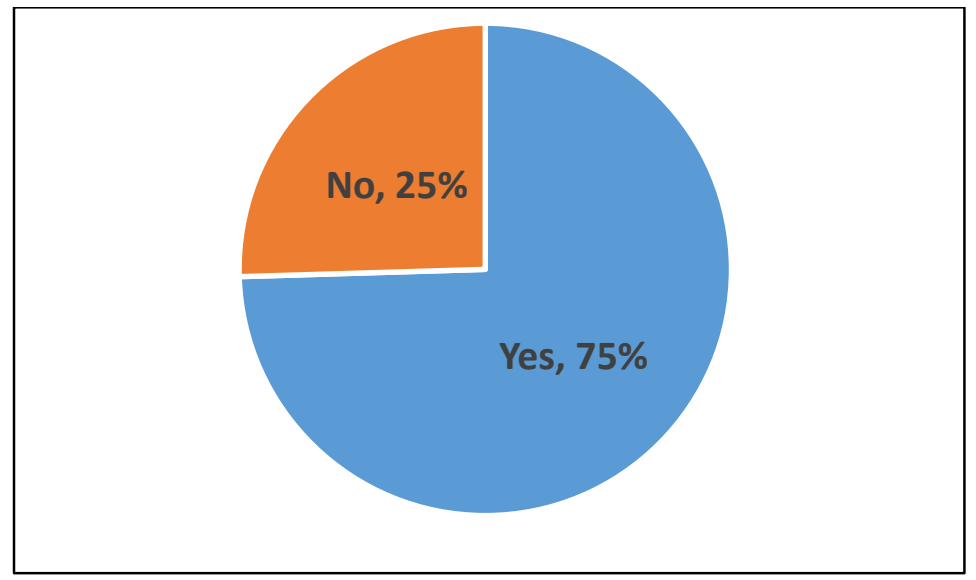

Figure 3.16 Web-Based Trainings

Transit managers also acknowledged that nearly $40 \%$ of agencies have some form of employee recognition program (Figure 3.17). Also, most larger agencies with more than 20 employees have some form of employee recognition program while very few of the smaller agencies offer employee rewards. Among those agencies with an employee recognition program, $80 \%$ issue certificates for outstanding work while nearly half award plaques to honor employees (Figure 3.18). Recognition letters and meals were also cited by more than $30 \%$ of respondents as rewards for employee excellence.

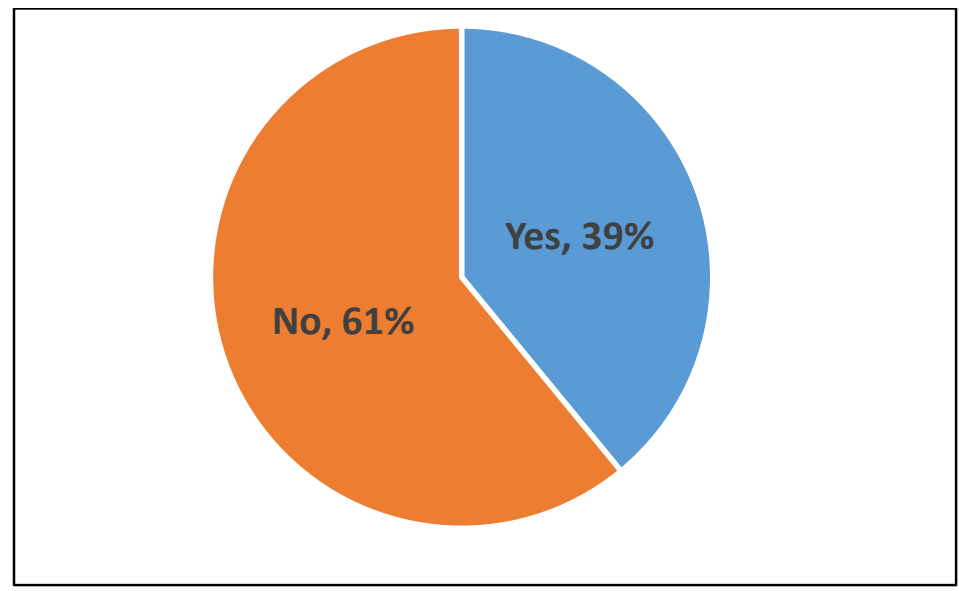

Figure 3.17 Agencies with Reward Recognition Programs 


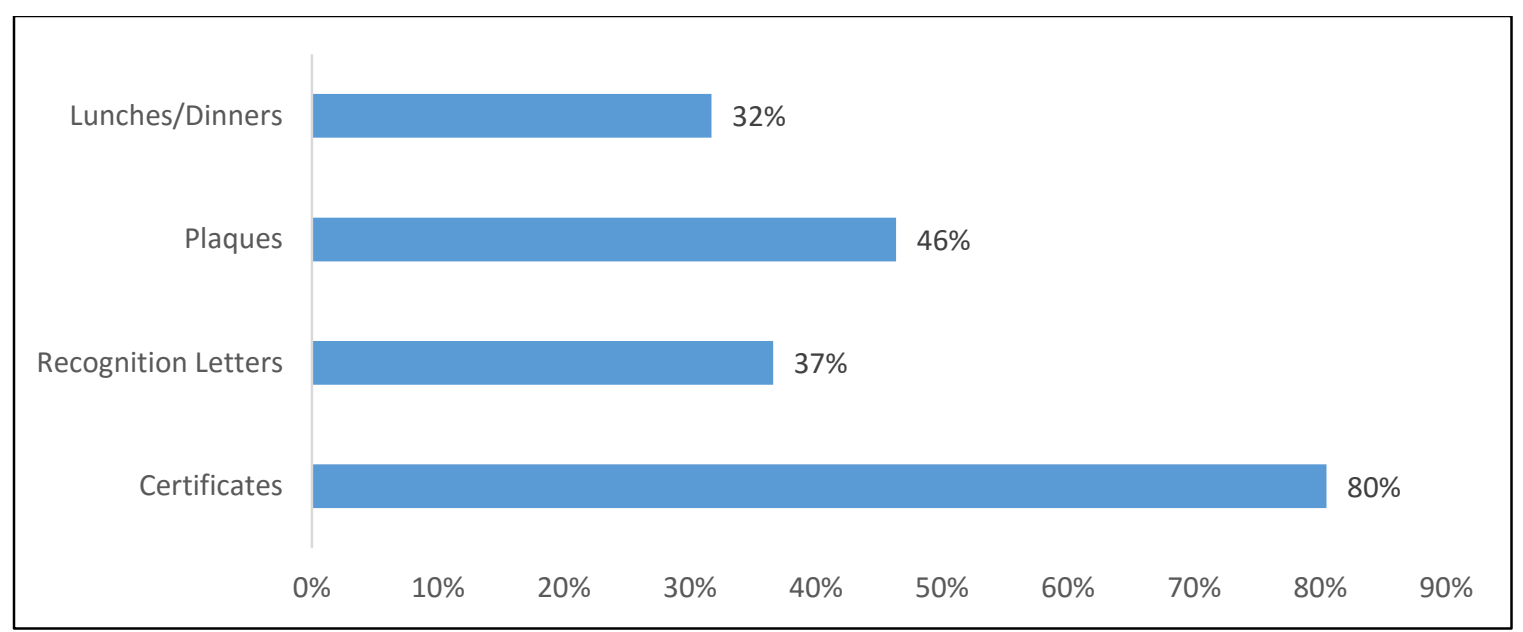

Figure 3.18 Employee Rewards Among Agencies with Reward Programs

Finally, survey participants were questioned regarding succession planning. Only $15 \%$ of agency respondents have some form of succession plan currently in place with the larger agency respondents, those with more than 20 employees, accounting for the vast majority of current plans (Figure 3.19). When asked to elaborate on their current succession plans, some agency managers highlighted one-on-one training as a succession planning technique to groom assistant managers for management positions. Others mentioned they have written procedures in place that cover management responsibilities as well as staff designated to work closely to familiarize new management personnel with agency rules and processes. A few respondents also cited goal setting with monthly reporting to their boards and human resource committees. Job shadowing by assistant managers was another method utilized by some as part of their succession planning process.

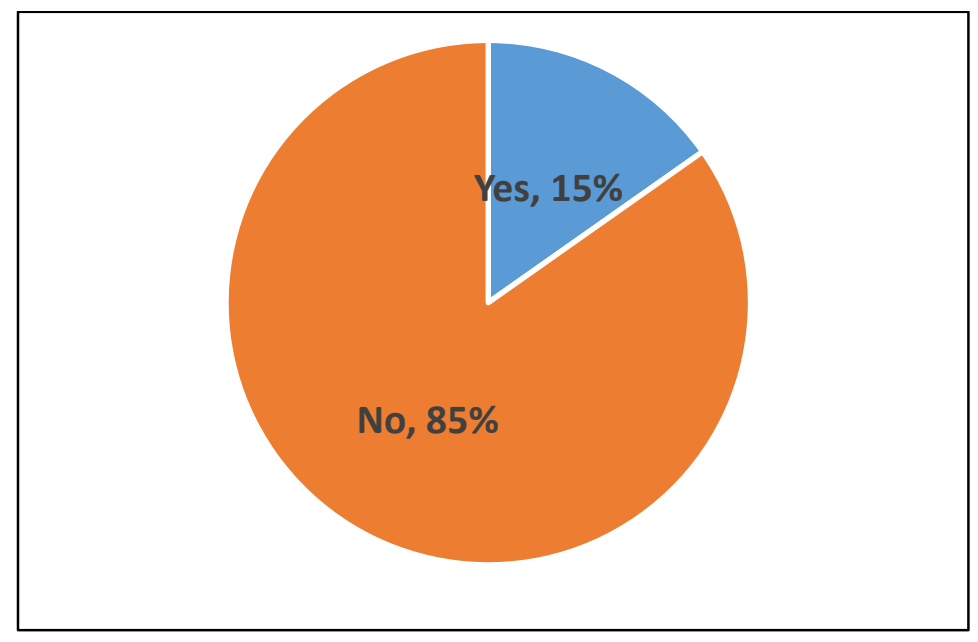

Figure 3.19 Agencies with Succession Plans 


\section{SUMMARY AND CONCLUSIONS}

As America's transportation workforce continues to age, there is an increased need to invest in workforce development to address the impending retirement tsunami. This is especially true within the small urban and rural transit industry. Literature review findings showed that 63 percent of U.S. transit workers are 45 years of age or older, and that significant job growth will occur during the next 10 years in both urban and rural communities (U.S. Department of Education 2015).

Recruitment efforts have highlighted the need to utilize national publications for job postings to increase the reach for potential qualified candidates. Training efforts emphasized the need for increased workforce development budgets while recognizing that funding such efforts is challenging during tight fiscal periods. Typically, training is the first place to cut when attempting to reduce transit agency costs (Anderson et al. 2010). Cutting training budgets within agencies must be mitigated to allow for needed employee training opportunities. To allow for employee growth and development, efforts must be made to stop reducing already small training budgets.

Survey findings included a cross-section of 160 viable responses from 40 different states. The majority of transit agency managers have been employed by their current agency for more than 15 years while $75 \%$ of total respondents were 50 years of age or older. One-third of respondents indicated they plan to retire within the next five years while only $15 \%$ have any viable succession plan currently in place to combat such high management turnover.

Details of succession plans varied considerably. Many respondents mentioned mentoring and one-on-one training as succession plan examples while others have current staff members designated to work with incoming management to familiarize them with agency rules and processes. Also concerning was that only $40 \%$ of respondents indicated having any type of employee recognition program in place. To improve employee morale and advancement opportunities from within, transit agencies must take the time to develop feasible succession plans and make an effort to reward employees for outstanding performance.

Training opportunity findings for both national and local levels focused on various topics from transit principles to emergency and human resource management. Overviews and training opportunities were emphasized with links to potential training sites listed for each organization (Appendix A). Focusing on potential web-based trainings may be practical for many rural transit agencies. These trainings are usually less costly and time consuming when factoring in the need for travel to traditional in-person classroom training. Survey results showed that inexperienced managers required transit principles training while training for more experienced managers should focus on leadership, business plan development, and emergency management. Transit principles, human resource management, and emergency management were found to be helpful trainings for employees seeking internal advancement within an agency.

The successful recruitment and training of workers who will be responsible for all aspects of transit operations is both critical and timely. Steps must be taken to ensure that proper planning ensures the future viability of the industry. Increased investments in employee development now will yield a future public transportation workforce with the knowledge and ability to serve rural America for generations to come. 


\section{BIBLIOGRAPHY}

American Public Transportation Association. Final Recommendations of APTA's Blue Ribbbon Panel on Workforce Development. n.d.

http://www.apta.com/resources/workforce/Documents/APTA-Blue-Ribbon-Panel-on-Workforce-

Development-Final-Report-and-Recommendations.pdf (accessed July 2015)

American Public Transportation Association. APTA Preliminary Skill Development and Training Needs Report. Washington, DC. July 2010.

American Public Transportation Association. Creating Sustainable Human Capital Investment: A Final Report of the 2012 APTA Workforce Development Task Force. Washington, DC. September 2012.

Anderson, Lance, Candace Blair Cronin, Daniel Fien-Helfman, Michelle Pohl, Brian Cronin, Ream Lazaro, Valerie Lazaro, and Anne Singleton. TCRP Report 139: Guidebook for Recruiting, Developing, and Retaining Transit Managers for Fixed-Route Bus and Paratransit Systems. Transit Cooperative Research Program, Washington, DC: Transportation Research Board of the National Academies, 2010.

APTA. American Public Transportation Association. http://www.apta.com/resources/profdev (accessed May 2016).

CTeL. The Center for Transportation e-Learning. http://www.ctelonline.com/ (accessed May 2016).

City of Charlotte. "Shared Leadership Learning Overview: A Mentoring Experience." City of Charlotte. May 16, 2016.

CTAA. Community Transportation Association of America.

http://web1.ctaa.org/webmodules/webarticles/anmviewer.asp?a=32\&z=36 (accessed May 2016).

ESPA. Easter Seals Project Action. http://www.projectaction.org/Training.aspx (accessed May 2016).

Federal Transit Administration. "Innovative Transit Workforce Development Program.” Federal Register. 77 (105). May 31, 2012.

Federal Transit Administration. "2011 Innovative Workforce Development Grants." http://www.fta.dot.gov/12351_14636.html (accessed July 2015).

Federal Transit Administration. "2012 Innovative Workforce Development Grants." http://www.fta.dot.gov/12351 14986.html (accessed July 2015).

FTA. Federal Transit Administration. https://www.transit.dot.gov/regulations-and-guidance (accessed May 2016).

KFH Group, Inc. TCRP Report 127: Employee Compensation Guidelines for Transit Providers in Rural and Small Urban Areas. Transit Cooperative Research Program, Washington, DC: Transportation Research Board of the National Academies, 2008.

Miles, Stephen A. "Succession Planning: How Everyone Does it Wrong." Forbes. July 30, 2009. http://www.forbes.com/2009/07/30/successionplanningfailuresleadershipgovernanceceos. html (accessed July 2015). 
Miles, Stephen A. "Succession Planning: How to Do it Right." Forbes. July 31, 2009.

http://www.forbes.com/2009/07/31/successionplanningrightleadershipgovernanceceos.

html (accessed July 2015).

NTI. National Transit Institute. http://www.ntionline.com/courses/ (accessed April 2016).

Potts, John F. and Maxine A. Marshall. TCRP Synthesis 71: Paratransit Manager's Skills, Qualifications, and Needs. Transit Cooperative Research Program, Washington, DC: Transportation Research Board of the National Academies, 2007.

RTAP. Rural Transit Assistance Program. http://nationalrtap.org/Training (accessed May 2016).

SURTC. Small Urban and Rural Transit Center. http://www.surtc.org/training/ (accessed April 2016).

U.S. Department of Education, Office of Career, Technical, and Adult Education. Strengthening Skills Training and Career Pathways across the Transportation Industry. Washington, DC: 2015.

Vogel, Brian H. TCRP Research Results Digest Number 45: Identification of the Critical Workforce Development Issues in the Transit Industry. Transit Cooperative Research Program, Washington, DC: Transportation Research Board of the National Academies, 2001. 


\title{
APPENDIX A.
}

\author{
Potential Training Opportunities
}

\section{National Training Organizations}

A number of national organizations provide training for rural transit agencies. Trainings range from manager-level education to opportunities for drivers and front-line personnel. Many also provide inperson as well as web-based training options. Following is a summary of many potential organizations that can provide training options for agencies.

\section{American Public Transportation Association (APTA)}

Overview: APTA's main goal is advancing public transportation. Members are public organizations focused in areas of fixed-route bus and demand-response public transportation, among others. Government agencies along with state DOTs also belong to APTA. Although its focus is on larger communities, many of its trainings are scalable and applicable to the needs of rural public transportation (APTA 2016).

Trainings: APTA offers both in-person and web-based trainings. Trainings focus specifically on relevant transit needs. APTA has worked extensively in workforce development and believe it is critical to attract and develop a workforce to continue the success of the public transportation industry.

Link: http://www.apta.com/resources/profdev

\section{Center for Transportation e-Learning (CTeL)}

Overview: CTeL provides an online learning system that focuses on courses targeting the small urban and rural transit industry. It uses eLearning technology to provide training to employees at remote agencies who are unable to participate in traditional classroom training. CTeL seeks to identify current training needs and provide training at the lowest possible cost while complementing various workforce development activities (CTeL 2016).

Trainings: CTeL offers five courses geared towards the rural public transit industry: Safety Training and Rural Transit, Community Transportation Supervisor, Wheelchair Securement, Hiring the Right Staff, and Performance Based Financial Management.

Link: http://www.ctelonline.com/

\section{Community Transportation Association of America (CTAA)}

Overview: Freedom, independence, dignity and choice are the values that CTAA strives to improve by increasing the mobility of rural America. Members believe that effective public transportation contributes greatly to the quality of life for those living in cities, towns and communities throughout the country (CTAA 2016).

Trainings: CTAA's trainings attempt to raise the standard of excellence within public transportation. It offers specific trainings as well as accreditation and certification in various areas. Specifically, they offer accreditation in safety and security for communities and public transit systems as a whole and offers certification courses in seven different areas. Its PASS Driver Certification Program is available online. Link: http://web1.ctaa.org/webmodules/webarticles/anmviewer.asp?a=32\&z=36 


\section{Easter Seals Project Action (ESPA)}

Overview: ESPA's mission is to "promote universal access to transportation for people with disabilities under federal law and beyond by partnering with transportation providers, the disability community and others through the provision of training, technical assistance, applied research, outreach and communication" (ESPA 2016).

Trainings: ESPA's disability focus has shown that improved access for people with disabilities often leads to better access for everyone. It has both on-line and in-person training programs centering on topics such as travel training and methods to enhance funding along with ADA topics such as alternative modes of transportation as well as common issues and best practices with lifts, ramps, and other securements. Link: http://www.nadtc.org/training-webinars/category/training-webinars/

\section{Federal Transit Administration (FTA)}

Overview: FTA is an agency within the U.S. Department of Transportation (USDOT). FTA supplies financial and technical support to local public transit systems. Various services that support small urban and rural transit are sponsored by FTA. It also oversees safety measures and aids in the development of innovative technology research (FTA 2016).

Trainings: Because of its role of providing financial assistance to operating systems, FTA provides guidance pertaining to the compliance with statutory and regulatory requirements. It also administers a national safety program and oversight process as well as the Transit Asset Management (TAM) program. This program assists agencies maintain their assets in a state of good repair. Other relevant trainings are also available in various subject areas.

Link: https://www.transit.dot.gov/regulations-and-guidance

\section{National and State Level Rural Transit Assistance Program (RTAP)}

Overview: The main goal of RTAP is to promote and help improve the efficiency and effectiveness of public transportation services in rural areas. It operates under a cooperative agreement between the Federal Transit Administration (FTA) and the Neponset Valley Transportation Management Association. (RTAP 2016). Both of these organizations have national- and state-level representatives.

Trainings: RTAP develops and distributes training materials, creates web-based applications, publishes best practices, and offers assistance to rural and tribal transit agencies. Training materials are available in print, online, or through its eLearning system. The eLearning system offers online courses with topics ranging from emergency management to how to deal with problem passengers. They also offer " 2 The Point Training" cards, refresher trainings on various topics for transit agency employees.

Links: National: http://nationalrtap.org/Training

State: http://nationalrtap.org/State-RTAP-Programs

\section{National Transit Institute (NTI)}

Overview: NTI was established to develop and deliver training for the public transit industry. Its mission is to "provide training, education, and clearinghouse services in support of public transportation and quality of life in the United States" (NTI 2016). NTI is part of Rutgers, The State University of New Jersey. Trainings: NTI offers both in-person and on-line training options. Much of their training focuses on urban transit issues, but many of these are transferable to smaller communities. Specifically, NTI has developed a course in rural transit technology and offers training related to financial planning, procurement for small- and medium-sized transit systems and leadership training that is applicable to all community sizes and types.

Link: http://www.ntionline.com/courses/ 


\section{Small Urban and Rural Transit Center (SURTC)}

Overview: SURTC was established to increase the mobility of small urban and rural residents through improved public transportation. Part of SURTC's mission is to provide training and education opportunities to transit system employees and individuals with an interest in the transit industry. SURTC is housed within the Upper Great Plains Transportation Institute at North Dakota State University (SURTC 2016).

Trainings: SURTC offers on-site trainings that focus on transit management and specific training workshops as well as John Maxwell leadership training courses. Workshop training topics include Transit I and Transit II, comprehensive 2-day courses teaching a wide range of topics for both experienced and inexperienced transit managers. Other courses include cost/benefit analysis, emergency management, frontline customer service and intelligent transportation systems, among others.

Link: http://www.surtc.org/training/

\section{Local Training Organizations}

Numerous training opportunities exist on both state and local levels. Below are links courtesy of APTA and CTAA that can be used to gain more information regarding local transit trainings that may be of interest to rural transit agencies. Many of these resources include state transit associations as well as state DOTs.

APTA Link: http://www.apta.com/resources/links/Pages/default.aspx

CTAA Link: http://web1.ctaa.org/webmodules/webarticles/anmviewer.asp?a=151\&z=5 


\section{APPENDIX B.}

Workforce Development Survey

Position

Transit Agency

City, State

1). How long have you been employed by this transit agency?

$0-5$ years

6-10 years

$11-15$ years

16- 20 years

Longer than 20 years

2). How long have you been employed at your current position within this agency?

$0-5$ years

6-10 years

$11-15$ years

16- 20 years

Longer than 20 years

3). How many different positions have you held within this transit agency?

1

2

3

4 or more

4). What is your age?

20-29 years old

30-39 years old 
40-49 years old

$50-59$ years old

60 years old or older

5). What is your current annual salary?

Less than $\$ 20,000$

$\$ 20,000-35,000$

$\$ 36,000-50,000$

$\$ 51,000-65,000$

$\$ 66,000-80,000$

More than $\$ 80,000$

6). How much longer do you anticipate working before retirement?

Less than 2 years

2-5 years

6-10 years

$11-15$ years

More than 15 years

7). How many people does your transit agency employ? (Include both full and part time employees)

(Do NOT include contracted employees)

$0-5$

6-10

11-15

$16-20$

21-30

More than 30

8). Are you aware of any of the following workforce development trainings that are currently available for agency managers? (Check all that apply) 
Public Transit Principles

Business Plan Development

Working with Local Governments

Human Resources

Emergency Management

Cost/Benefit Analysis

Other

9). Have you attended any kind of workforce development training within the past 5 years?

Yes

No

10). If yes, how many workforce development trainings have you attended within the past 5 years?

$1-2$

3-4

5-6

$7-8$

9 or more trainings

11). Have you found most training(s) to be helpful in doing your job?

Yes

No

12). If yes, please explain which trainings have been most useful and why.

13). Which of the following workforce development trainings have you not attended, but believe would be helpful within your current job? (Check all that apply)

Transit Principles

Business Plan Development

Working with Local Governments

Human Resources

Emergency Management 
Cost/Benefit Analysis

Other

14). Are there workforce development trainings that are not currently being offered that would be beneficial to your agency? If yes, please explain...

15). Are there workforce development trainings currently being offered that you would like to take but cannot?

Yes

No

If Yes, why,

Not enough time

Not enough funding available

Trainings are too long and time consuming

Trainings schedules do not work with my schedule

Distance to training site too far

Other

16). Are there workforce development training opportunities for employees within your transit agency who are interested in further developing their skills and being promoted? If yes, please list...

17). What workforce development trainings do you believe would be most beneficial for employees in your agency interested in further developing their skills and being promoted? (Check all that apply)

Transit Principles

Business Plan Development

Working with Local Governments

Human Resources

Emergency Management 
Cost/Benefit Analysis

Other

18). Have you ever taken any kind of web based training?

Yes

No

If Yes, what kind of training did you take, and did you find it helpful in doing your job? -

19). Does your transit agency have an employee reward and recognition program?

Yes

No

20). If yes, in what ways are your employees recognized? (Check all that apply)

Certificates

Recognition Letters

Plaques

Lunches/Dinners

Other ways

21). Does your agency have a succession plan that highlights steps to be taken by a new transit manager if the current transit manager leaves the agency or retires?

Yes

No

22). If yes, please explain your succession plan process. 